\title{
BROWN V LEYDS NO (1897) 4 OR 17: A CONSTITUTIONAL DRAMA IN FOUR ACTS. \\ ACT THREE: THE KING'S VOICE SPEAKS THROUGH THE 1858 ZAR CONSTITUTION TO PRESIDENT AND CHIEF JUSTICE (1884-1895)
}

\section{Derek van der Merwe*}

\section{ABSTRACT}

This is the third in a series of articles on the historical and jurisprudential background to the well-known case of Brown v Leyds NO (1897) 4 OR 17. Chief Justice Kotzé's judgement in this case was his ultimate expression of the centrality of the 1858 Grondwet (Constitution) of the Zuid-Afrikaansche Republiek to determine the extent and nature of legislative, executive and judicial powers in a constitutional democracy. The judgement set in train a series of events that led to the Chief Justice's dismissal from office by State President Kruger in 1898. This article traces Chief Justice Kotzé's gradual conversion, over a ten-year period, from a judge who uncomfortably acknowledged judicial subservience to unfettered legislative authority, to an activist judge (influenced by Marbury $v$ Madison) who was confidently prepared to assert judicial independence and constitutional supremacy over presidential and legislative

* Emeritus Professor of Law, University of Johannesburg. 
fiat. This conversion is described by means of an analysis of a series of judgements from the 1880s and early 1890s. The analyses also embed the judgements in the social, economic and political events (chief among which was the discovery of the main gold reef on the Witwatersrand in 1886) that shaped and ultimately determined Kotzé's damascene conversion from positivist lawyer to activist constitutional judge within a ten-year period. An attempt is also made to describe the personalities of the three main characters in the unfolding drama (Paul Kruger, John Kotzé and the state secretary, Willem Leyds) and how their respective ambitions, fears and prejudices influenced Kotzé in his judgements. This background knowledge is essential for a full understanding of why Kotzé adopted his radical stance in the Brown case, why it had such powerful political repercussions, why Kruger subsequently reacted in the way he did, and why Kotzé's approach was, in the final analysis, wrong in law.

Keywords: 1858 Grondwet; constitution; constitutional democracy; Volksraad; Boers; supreme authority; sovereign authority; highest authority; volk; uitlanders; judicial independence; Paul Kruger; John Kotzé; John Austin; Hugo Nellmapius; freedom of the press

\section{Introduction}

The Boers had gone to war in December 1880 to fight for their independence from Great Britain. The British had sued for peace in March 1881 and the peace terms were eventually captured in the Pretoria Convention, formally agreed to by both parties in October 1881. ${ }^{1}$ The Convention provided for the retrocession of the Zuid-Afrikaansche Republiek (ZAR), that is, full self-government, subject, though, to British suzerainty over the affairs of - what the British continued to call - the Transvaal. This meant that Great Britain controlled the foreign affairs of the ZAR, its relationships with its African inhabitants and neighbours and also protected the interests of British citizens resident in the ZAR. The government and the Volksraad of the $Z A R$, though they chafed at being treated as suzerains of the British, deemed themselves to be de facto independent. For this reason they set about rebuilding and strengthening the pre-1877 republican institutions and creating the conditions for economic independence. One such institution was the Supreme Court of the ZAR. In August 1881 John Kotzé was therefore sworn in as chief justice. Piet Burgers and Christoffel Brand were sworn in as additional judges in December 1882 and January 1883 respectively. ${ }^{2}$

The government and the Volksraad of the ZAR faced huge obstacles to creating conditions in which the economy could flourish. The war and its aftermath left the majority of the Boers (those in the rural areas in particular) in the same straitened

1 Kotzé 1934: 784-802 provides much detail in the dual capacity of first-hand observer of and participant in the political events that led to the Pretoria Convention. The Dutch text of the Pretoria Convention appears in Jeppe \& Kotzé 1887: 996-1009.

2 See Kotzé 1941: 18-23. On Burgers and Brand see Roberts 1942: 352 and 350 respectively. 
circumstances as before, and as unwilling and unable as ever to pay taxes; many foreigners (uitlanders) had left in the wake of the war, taking commercial activities and business acumen with them; the goldfields in the Lydenburg mountains had yielded about as much as they could; and the Africans continued their aggression towards the European usurpers of their land. When the Volksraad first met in August 1881, the desperate need to improve state revenue was a dominant theme. Two decisions in particular, taken under conditions of real economic hardship, were to have far-reaching consequences.

The first was the approval, as general economic policy, to grant to individuals or companies the sole right to produce, manufacture or distribute products or goods for a specified period and against payment to the government of stipulated licence fees or a share in the profits generated. This was the so-called concessions policy. ${ }^{3}$ It was hardly unknown in the pre-1877 republican economy to grant to individuals sole rights to large chunks of the national economy (prime examples include Piet Marais's sole right to prospect for gold in the $1850 \mathrm{~s}^{4}$ and Alexander McCorkindale's arrangements with MW Pretorius and an (initially) willing Volksraad for sole control over large swathes of land). ${ }^{5}$ Nevertheless, it was a novel decision to elevate to a formal policy the granting of sole commercial rights without a competitive process to facilitate the industrialisation of the economy and to make it less reliant on expensive (largely British) imports. Alois Hugo Nellmapius is credited with introducing this notion to State President Paul Kruger and his government. ${ }^{6}$

Hungarian-born Hugo Nellmapius had come to the ZAR via Delagoa Bay in 1873 with a group of young Dutch adventure seekers after completing his engineering studies in the Netherlands. They were lured by the promise of good money to be made on the recently discovered Lydenburg goldfields. Nellmapius soon gained a reputation for entrepreneurial enterprise and gained the confidence of the republican authorities when he devised a workable transport system between the Lydenburg goldfields and Delagoa Bay through the malaria-infested Lowveld. Later he applied his skills and expertise in many fields of endeavour and by the time of the retrocession in 1881 he was a successful farmer to the east of modern Tshwane and a confidant of the State President, Paul Kruger, and the commandant-general, Piet Joubert. He therefore had little difficulty in persuading Paul Kruger and his executive, and, later, the Volksraad, of the benefits of a concessions-based industrialisation policy for the struggling republic. In 1881 the first concessions were granted by the Volksraad to Hugo Nellmapius to distil liquor and to produce sugar in a factory on his Hatherley farm (appropriately called De Eerste Fabrieken - the first factories)

3 On which see, in particular, Nathan 1941: 185-194; Marais 1961: 23-45 esp 23-33; Kaye 1978: 37-41, 42-44; and Wheatcroft 1986: 124-127.

4 The agreement granting Marais the sole right to prospect for gold in the whole of the ZAR is published in Volksraadsnotule II: 519-521. On Marais, see, most recently, Davenport 2013: 76-79.

$5 \quad$ See Van der Merwe 2017b: 139-143.

6 On Nellmapius, see Kaye's compact, but informative, biography: Kaye 1978: passim. 
and to manufacture gunpowder and ammunition. These concessions alone would make him and his business associates very rich, very quickly. Soon he would become an important interlocutor between the Kruger government and foreign entrepreneurs seeking risk-free commercial and industrial opportunities in the republic. He even lent the state money and, so it was rumoured, paid for the construction of the new presidential home in Church Street in 1884. ${ }^{7}$ A myriad of concessions for every conceivable commercial opportunity was awarded by the Volksraad in the 1880 s (including one to a Dutch consortium for the building of the much-anticipated railway line between Pretoria and Delagoa Bay). These concessions were to become really lucrative and extremely contentious when the vast Witwatersrand goldfields came into full production from 1887 onwards. The favoured few became rich and the rest continued to be excluded from competing for commercial benefit.

The second decision taken by the Volksraad in its 1881 session concerned the estate of Alexander McCorkindale. He had died insolvent in 1871 and left his financial affairs in a mess. ${ }^{8}$ After years of trying to make sense of McCorkindale's dealings with MW Pretorius and the Volksraad, a settlement agreement regarding the extent of the landholdings of the estate in the New Scotland region and what needed to be returned to the state had been reached in January 1877 between the government of the $Z A R$ (represented by Paul Kruger and EJP Jorissen) and the executors of the estate. ${ }^{9}$ Upon retrocession, the Volksraad decided, in November 1881, to enforce the settlement agreement which had been in abeyance during the annexation years. ${ }^{10}$ The state needed the resources badly.

When the executors (different from those who had signed the agreement in 1877) disputed the interpretation of the terms of the settlement, the Executive Council launched an investigation. In January 1884 it consequently demanded that fortyfive farms in the region of Londina in New Scotland (in what is today the Ermelo district of the Mpumalanga Province), the subject of a dispute since 1868, must be transferred to the state. When the executors continued to dispute the state's right to demand the transfer of these farms, the Executive Council, impatient of the matter that had been dragging on for thirteen years, passed a resolution in March 1884, directing the registrar of deeds not to transfer any of the farms or register a mortgage over any of them, and further directing the surveyor-general not to approve diagrams for any of the farms. ${ }^{11}$

In May 1883 Paul Kruger was elected state president of the $Z A R$, after having secured substantially more votes than his opponent, Piet Joubert. In August of the same year Kruger led a delegation to London to negotiate better terms for the ZAR

7 Idem 45.

8 See Pelzer 1970: 161-162.

9 Ibid.

10 The terms of the settlement agreement are contained in Staatsprokureurstukke 25/1877; see, too, ZAR Staatskoerant 52 (art 92: Volksraad meeting minutes of 29 May 1876).

11 See ZAR Staatskoerant 57 of 1881 (art 343: Volksraad meeting minutes of 4 Nov 1881). 
than those set in the Pretoria Convention. ${ }^{12}$ They won a number of concessions from the British, important among which was the removal from the Convention of any reference to the much-resented term "suzerainty" (although Great Britain still retained a veto right over treaties concluded by the $Z A R$ with other countries). The revised Convention (it became known as the London Convention) was signed between the ZAR and Great Britain in February 1884. Apart from the removal of the term "suzerainty", it also recognised the name of the Transvaal as the Zuid-Afrikaansche Republiek and redefined the south-western boundary of the republic. The republican government had good reason to feel that, politically if not economically, the ZAR functioned at enough of an arm's length from Great Britain to satisfy its nationalist sentiments.

Kruger also, during a visit to the Netherlands, managed to secure the appointment of twenty-five-year old WJ (Willem) Leyds, who had recently graduated doctor iuris from the University of Amsterdam, as state attorney for the ZAR. ${ }^{13}$ Leyds would play an important role in the build-up to the constitutional crisis generated by Chief Justice Kotzé's 1897 judgement in Brown v Leyds, not least because of the mutual animosity between him and Kotzé.

When Kruger returned to the ZAR in September 1884, there was a confident air about the government: peace had been established not only with the African tribes, but also among the tribes; planning was underway for the construction of a railway line to link Pretoria with the Delagoa Bay harbour; and the concessions policy had begun to create wealth, even if only for a privileged minority.

\section{Kotzé upholds Volksraad supremacy: Executors of McCorkindale v Bok NO (1884) 1 SAR 202}

The executors of the McCorkindale estate were not going to relinquish control of forty-five farms without a fight. ${ }^{14}$ When the Executive Council's resolution was published in the Government Gazette in March 1884, they applied to the Supreme Court for a rule nisi, calling upon the government (represented by the state secretary, WE Bok) to provide reasons why it should not be ordered to withdraw the notice that contained the resolution directing the registrar of deeds not to allow the transfer of any of the forty-five farms or to register mortgages over any of them, and further directing the surveyor-general not to approve any diagrams of the farms; and why it should not be ordered to rather bring an action in law against the McCorkindale

12 On the above, see Executors of McCorkindale v Bok NO (1884) 1 SAR 202 at 203-204.

13 On Kruger's election as state president and the negotiations leading up to the London Convention, see, inter alia, Nathan 1941: 197-200 and 200-209. The Dutch text of the London Convention appears in Jeppe \& Kotzé 1887: 1250-1259.

14 See Van Niekerk 1985: 16-19; and Bossenbroek 2014: 3-13. 
estate. In other words, why it should be allowed to exercise arbitrary executive authority to resolve a legal dispute, long-standing though it was.

Brand $\mathrm{J}$ granted the rule nisi. On the return day the court expressed the view to the government representative that the Executive Council had exceeded its powers in passing the resolution and should rather have applied to court for an interdict to prevent the registrar of deeds and the surveyor-general from executing requests from the estate's executors on the basis that the government's rights would be infringed. The court, in fact, gave the government time to consider withdrawing the notice in the Gazette and to rather apply for an interdict to protect its rights. The acting state attorney informed the court that the government had no desire to withdraw the notice, upon which the court expressed its regret and reserved its judgement. Before the judgement was given, however, the Volksraad, having convened for its 1884 session, resolved in September to confirm the earlier resolution of the Executive Council on the basis that the government had no choice other than to execute the earlier Volksraad resolution on the matter taken in 1881. It further authorised the government to take the legal steps necessary for the forty-five Londina farms to be returned to the state.

On 17 September 1884 the government argued before Kotzé CJ and Burgers $\mathrm{J}$ that the matter had been dispensed with by the resolution of the Volksraad. The executors requested, and were granted, leave to argue that, constitutionally, the Volksraad resolution had no force of law and that the court was therefore not bound to recognise it; the more so as it had been passed on a matter that was the subject of a pending judgement.

For the executors appeared Fred Kleyn, a former state attorney during the pre-1877 dispensation (and lead representative of the ZAR in the 1872 arbitration proceedings that had led to the Keate Award) and SG Jorissen. The latter was the son of EJP Jorissen and was married to a daughter of the former state president, Thomas Burgers. He had qualified doctor iuris in Holland and was among a number of young, professional Hollanders who had emigrated to the $Z A R$ after the retrocession. ${ }^{15}$

Kleyn and SG Jorissen advanced four arguments in support of their contention that the Volksraad had no constitutional authority to pass its September resolution and that it therefore had no legal force:

(i) Article 12 of the 1858 Grondwet (the Constitution) - read with article 66 - was pivotal in this regard. Article 12 provided as follows (translated from the original Dutch): ${ }^{16}$

The people assign legislative authority to a Volksraad, the highest authority in the land, comprising representatives or mandatories of the people, elected by enfranchised citizens; however, only to the extent that the people will be given a period of three months to provide

15 For the background information that follows, see McCorkindale (n 12) at 203-205.

16 On SG Jorissen, see Roberts 1942: 366; see, too, Kahn 1991: 104-106 and sources cited. 
its comments to the Volksraad on a proposed law should it wish to do so; except those laws which brook no delay. ${ }^{17}$

This provision prescribed the mode in which an enactment of the Volksraad can become a law "in the true sense of the term". The Volksraad resolution did not conform to the requirements for law-making provided for in article 12: it had not been published for public comment three months prior to its discussion, nor was it of such a nature that the notice period could be dispensed with, because it brooked no delay. The resolution, therefore, had no force of law. It is true that section 2 of the 1859 second appendix to the Grondwet prescribed that a court shall respect ("eerbiedig") all Volksraad resolutions as law and no court would be allowed to pass any judgement over it or subject it to scrutiny. ${ }^{18}$ The context in which this provision appears in the second appendix made it clear that this provision had reference only to matters concerning property disputes that had arisen prior to the approval of the Grondwet and had been or were in the process of being dispensed with by the Volksraad. It had no bearing on Volksraad resolutions passed in other contexts, such as the one under discussion. ${ }^{19}$

(ii) The Grondwet is the constitution of the state and therefore stands on a different footing to other laws. By means of its provisions, the people (the volk) entrusted legislative power to the Volksraad, subject to certain constraints (as primarily provided for in article 12). The Volksraad was bound by these constraints, since the volk and not the Volksraad are the "sovereign or supreme" power in the state. The Volksraad cannot legislate by means of resolutions, since it does not have the constitutional authority to do so. If it were to do so, as in the present case, the judicial authority has the power to nullify the legal effect of the resolution. ${ }^{20}$

(iii) Even assuming that a Volksraad resolution has the force of law, the Volksraad cannot tacitly alter a law as fundamentally important as the Grondwet; passing a resolution with the intention to create valid law amounts to a tacit amendment of the terms of article 12 of the Grondwet. This cannot be done. ${ }^{21}$

(iv) Even if it has the force of law, no Volksraad resolution may interfere in a matter pending before a court of law. Such interference would amount to a violation of the independence of the judiciary, guaranteed by the Grondwet. ${ }^{22}$

17 The legislative process described in art 12 was confirmed in ss 71-72 of the 1882 Volksraad rules of procedure.

18 See Jeppe \& Kotzé 1887: 117.

19 This argument is reflected in the judgement of Kotzé CJ in McCorkindale (n 12) at 207-208. The report contains the English translation of the original Dutch judgement.

20 The argument is reflected at idem 209.

21 Idem 215-216.

22 Idem 216. Judicial independence was guaranteed in arts 15 and 62 of the Grondwet. 
Kotzé CJ delivered the judgement of the court (Burgers J concurred). His judgement began with the assertion that the question before the court was "of the greatest importance" and "embraces a very serious constitutional doctrine". ${ }^{23}$

He made short shrift of the first argument. ${ }^{24}$ A Volksraad resolution passed as law under circumstances where it could not have been delayed for the prescribed three-month period, would no doubt be contrary to the spirit of the Grondwet. It is, however, in the nature of a resolution that it cannot be published for three months beforehand. Nevertheless, this does not mean that it has no force of law. Reference to the statute book would make it abundantly clear that resolutions had always been regarded as having the force of law. Furthermore, the wording of article 220 of the Grondwet, namely that " $[a] l l$ prior laws and resolutions, contrary to the tenor of these laws, are hereby repealed", was confirmation that the Grondwet itself placed laws and resolutions on the same footing. In article 1 of the 1859 first supplement, too, it is stated that the "wetboek" of Van der Linden ${ }^{25}$ would remain the "wetboek" (that is, a primary source of the common law of the ZAR) of the state, unless it conflicted with the Grondwet, other laws or Volksraad resolutions; clearly, here too laws and resolutions were treated the same. He agreed with counsel's contention that article 2 of the second supplement referred to specific transition measures in 1858 and 1859 and had no application in present circumstances.

According to Kotzé CJ the proper conclusion was that, since resolutions had always been considered to have the force of law, resolutions properly passed and published have the force of law "by our local laws". ${ }^{26}$

His response to the second argument was the essence of the judgement. ${ }^{27}$ Does the Grondwet have a higher standing than other laws? If so, the people (the volk), using the Grondwet as its instrument, entrusted law-making powers to the Volksraad subject to certain restrictions, which makes the volk, and not the Volksraad, the "sovereign or supreme power" in the state. If the Volksraad makes laws contrary to the restrictions imposed upon it by the volk-through-the-Grondwet, it exceeds its authority and a court can declare such actions invalid in law.

This argument was four-square in line with the constitutional doctrine that applies in the United States of America. The US Constitution determines the lawmaking powers of the US Congress; as such, Congress is not the so-called sovereign or supreme power in the state. If Congress exceeded its powers, the US Supreme Court had the power to void its unconstitutional actions. The US Constitution and the ZAR Grondwet, wrote Kotzé CJ, were different creatures. The Grondwet did not occupy a position higher than any other law in the ZAR ("It ought not to be so,

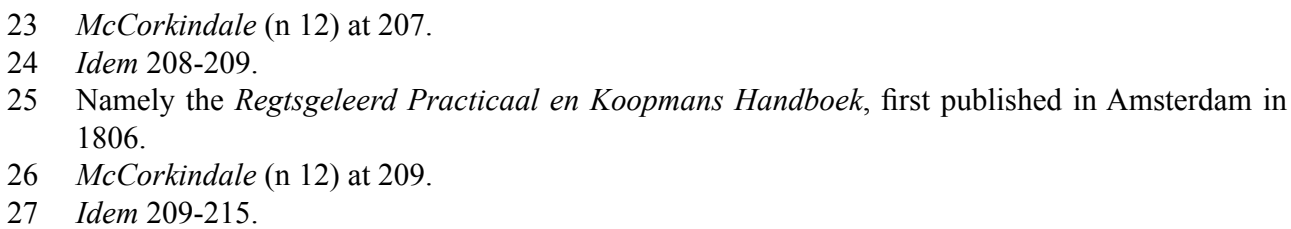


but such is unfortunately the case"). ${ }^{28}$ Having existed for many years prior to the Grondwet, the Volksraad created the Grondwet at Rustenburg in February 1858, not the other way round. It was not a subservient creature of the constitution, as Congress is in the United States, the latter having been created by the US Constitution. The constitutional position of the Volksraad was more in line with that of the Queen-inParliament in Great Britain or of the Crown-and-States-General of the Netherlands, in that its power to make laws resided in its sovereignty, its supreme power in the state..$^{29}$

The Grondwet itself states (in arts 12 and 29) that the Volksraad is the highest power ("hoogste gezag") in the state and repeatedly, since 1859, it has amended the Grondwet, by law and by resolution. There is no law that prohibits it from doing so, "even though it may be most desirable that the Grondwet should not be treated and altered in the ordinary way". Even if there were such a legal prohibition, the Volksraad - the highest power in the state - would not be legally, but only morally, bound by it. The Supreme Court does not have the power to annul a law because it deems it to be unconstitutional. If it were to do so, it would raise itself above the Volksraad, which would be unconstitutional. ${ }^{30}$

Highest or sovereign power limited by law was a contradiction in terms; a sovereign power is above the law. What was the source of the Volksraad's power, if not the law? Accepted political wisdom among the Boers, wrote Kotze CJ, ${ }^{31}$ was that in the ZAR the people are King ("de volk heeft de Koningstem"). This, he said, was "true in a moral, but certainly not in a legal, sense". ${ }^{32}$ This judicial opinion represented a major departure from Boer political convention since Voortrekker times. Boer wisdom would have it that in their republic, the people (the volk) would be governed by the people for the people. Sovereignty resided in the people, nowhere else. That, said Kotzé CJ, was only true in a moral sense, not in a legal sense. Actions of the Volksraad at variance with the "opinion and sentiment of the people" (as could be found in the Grondwet) exacted moral sanction only. ${ }^{33}$

Kotzé CJ was driven to adopt this contrary line of thought and to reinforce the distinction between the moral and the legal throughout his judgement, because he was strongly influenced by the writings of John Austin. ${ }^{34}$ Austin, who died in 1859, was Professor of Jurisprudence at the University of London, where John Kotzé graduated LLB in 1872. Austin's Lectures on Jurisprudence, or the Philosophy of Positive Law, published posthumously in 1869, the year Kotzé arrived in London, was the primary vehicle for the propagation of his so-called command theory of law.

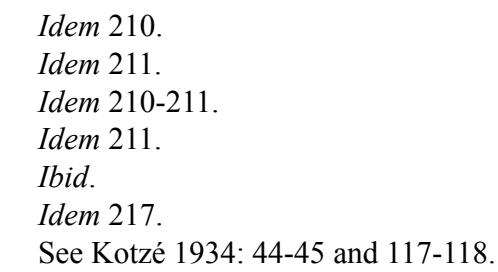


A legal positivist to the core, he extolled a "scientific jurisprudence" that greatly appealed to the young Kotzé who studied his writings avidly.

It was from Austin's Lectures on Jurisprudence that he extracted the notion that the US Congress with the US president is only a subordinate power of the US government (and therefore clearly distinguishable from the British Queen-inParliament); that the supreme power to make laws and the notion of sovereignty are "convertible terms"; that the sovereign, not subject to any legal limitation, is above the law (and that therefore the notion that "the people are sovereign" - de volk heeft de Koningstem - is true only in a moral sense); that the laws passed by a supreme legislature might be immoral or irreligious or unconstitutional "in the broad sense", but they cannot be illegal; that no legislature can bind its successor, but can merely "recommend or advise") its successor; and that the US Supreme Court can test the constitutional validity of laws passed by Congress, because the US government is in the form of a federal union, and because this is not the case in Great Britain, courts cannot test the validity of laws passed by the sovereign legislature. ${ }^{35}$

Since the Volksraad is the supreme power in the state, it is under no legal obligations, "[i]t is merely obliged by moral sanctions, by the opinion and sentiment of the people". ${ }^{36}$ As such, no Volksraad can be bound by its predecessor, and therefore the provisions contained in article 12 of the Grondwet for law-making can be no more than a directive to a subsequent legislature which it was free to follow or not. ${ }^{37}$ If the Volksraad of 1884 passed a resolution that, though not in the form of a law as provided for in the Grondwet, it had clearly intended to be observed as a law, then it is a law, for the will of the legislator is law. ${ }^{38}$

In his judgement he dismissed the opposing view expressed by a Dutch jurist, CW Opzoomer of Utrecht University. ${ }^{39}$ Opzoomer's view, influenced by American constitutional scholarship, was that the legislature was bound to comply with the provisions of the constitution (the Dutch Constitution in his case) and equally a court was duty-bound to declare invalid laws passed in an unconstitutional manner. Kotzé CJ rejected this view (as did other Dutch authorities he referenced), because he "confounds what is with what ought to be" (quoting John Austin). ${ }^{40}$ Opzoomer,

35 On the above references to Austin, see Kotzé CJ's judgement in McCorkindale (n 12) at 210-211 and 215. Aware of his obligation not to stray too far from Roman-Dutch authority, Kotzé CJ cited De Groot's De Jure Belli ac Pacis 137 and 2412 for the contention that supreme power and sovereign power are convertible terms and that a legislature therefore cannot bind its successor.

36 Idem 217.

37 Idem 212.

38 Ibid. In support of the contention that the will of the legislator is law, he cited as authority his own translation of Simon van Leeuwen's Het Rooms-Hollands-Regt, namely Roman-Dutch Law 141 ("The bare will and pleasure of the sovereign power are a law to its subjects"). The translation, dedicated to Sir Henry de Villiers, Chief Justice of the Cape Colony, was published in London in 1881 .

39 See his lengthy discussion of Opzoomer's views at idem 212-215. Opzoomer was a jurist, philosopher and theologian, attached for many years to Utrecht University.

40 Idem 213. 
wrote Kotzé CJ, seems to have been unacquainted with the "doctrine" of Austin "regarding the true and real position of a supreme or sovereign legislature", namely that the legislature's supreme authority can never give way to a judge's view on whether or not a law conforms to constitutional provisions. ${ }^{41}$

The third argument advanced on behalf of McCorkindale's executors was that, even assuming that the Volksraad's resolution was a law properly so called, it could not tacitly alter a law as important as the Grondwet, which is in effect what it did when it ignored the Grondwet provisions for law-making. Kotzé CJ swept aside this argument. A resolution has the force of law, and the Grondwet is like any other law passed by the Volksraad; the ordinary rule of interpretation therefore applies, namely that a prior law may be repealed by a later law, both expressly and by clear and necessary implication, that is, tacitly.

The fourth argument was that no law is binding if it interferes with a pending case. This is because, were it not so, judicial independence would be undermined, which in turn "jeopardises the liberty of the citizens". ${ }^{42}$

This "most eloquent" argument, wrote Kotzé CJ, "mixes up the legal with the moral". ${ }^{43}$ The Volksraad is the highest or supreme power in the state, therefore a court cannot curb or restrain it, however much the legislature is "morally bound not to encroach on the domain of the Court". ${ }^{44}$ If it were to neglect this moral obligation, then it might lead to forced resignation of the judges, loss of confidence in the legislature, loss of citizen liberty and the replacement of independence with despotism. ${ }^{45}$ Fourteen years later, in the aftermath of Kotzé CJ's Brown v Leyds judgement, the perceived violation of the proper relationship between legislature and judiciary led to Kotzé's dismissal and to accusations that citizens' liberties were endangered and that despotism reigned.

In the concluding portion of his judgement, Kotzé CJ acknowledged that English jurists of the eminence of Blackstone and Broom held the view that a law or statute that is "contrary to public right and reason, the law of nature, or the law of God", is void and should not be observed. This view, said Kotzé CJ, with reference to his favourite dogma, lost sight of the distinction between law and morality. John Austin in his Lectures convincingly refuted that view. A judge's duty is to explain and enforce the law, not to make law. ${ }^{46}$

Clearly uncomfortable with the carte blanche his judgement had bestowed upon the government of the $Z A R$, Kotzé $\mathrm{CJ}$ returned to the theme of judicial independence at the end of his judgement. The Executive Council, he wrote, was not competent to take the resolution it did in March 1884. In fact, it was not necessary to do so, as it

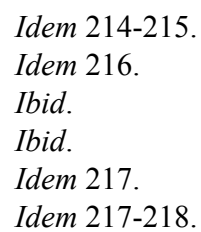


could have approached the court for an interdict to protect its rights (as in fact the court had intimated during argument) or it could have waited for the Volksraad to assemble and for it to pass the required resolution. When the Volksraad confirmed the Executive Council resolution in September, it created the appearance of an interference by it in a case that was pending, although - Kotzé CJ hastened to point out - it was clear that the Volksraad did not intend to do so, but merely meant to bring to final conclusion a matter that had dragged on for longer than a decade. In the same careful vein of expression, Kotzé CJ saw fit to make the point that "even the semblance of interference" should be "studiously" avoided, as judicial independence was one of the pillars of the state and the "inviolability of the Court is inseparably connected with the welfare and independence of the Republic". ${ }^{47}$

Kotzé CJ had no desire to antagonise the executive (Paul Kruger was in Europe at the time of the passing of the resolutions, but would surely have agreed with the approach adopted by the Executive Council then led by Piet Joubert), hence the careful language. Too careful, it would seem: in fact, the Volksraad resolution did not merely "appear" to interfere with a pending case, it was a clear infringement, whatever the intention of the legislature. Kotzé CJ was at pains, at the conclusion of the judgement, to send a message to the government to heed the rule of law (he did not use this expression, though) and not to overstep its boundaries, however diplomatically he couched his remonstration. In subsequent years, the government would not heed the warning and Kotzé would develop the confidence to shed the language of diplomacy.

Kotzé CJ thus rejected all four arguments made on behalf of the executors of McCorkindale's estate.

Burgers J concurred in the judgement of Kotzé CJ. A year earlier he, with Brand $\mathrm{J}$, had had occasion to decide a claim for damages for wrongful dismissal instituted by one Nabal against the state. ${ }^{48} \mathrm{Nabal}$, employed in the civil service during the annexation period, continued in employ after the retrocession, but such employment was deemed provisional. At the end of 1881, the Volksraad resolved to terminate his employment (along with a number of others in a similar position). It provided no reasons and offered no compensation. Burgers J dismissed Nabal's claim for damages. He did so on the grounds (specious, as it turned out in light of Kotzé CJ's judgement in McCorkindale) that article 2 of the 1859 second supplement to the Grondwet provided that all Volksraad resolutions were deemed to be law and could not be the subject of judicial contestation. So, his view was then, as in McCorkindale, that a Volksraad resolution was law, only his reason was different. No wonder he had nothing to add to Kotzé's judgement.

Kotzé CJ's judgement in McCorkindale was executive-minded - albeit grudgingly - but it did exhibit one important departure from accepted political

$47 \quad$ Idem 219.

48 Nabal $v$ Bok (1883) 1 SAR 60 at 60-62. 
wisdom in the Boer Republic. This was in respect of the importance attached to the voice of the people (the volkstem). The fathers of the 1858 Grondwet (the likes of MW Pretorius, Stephanus Schoeman, Cornelis Potgieter, William Robinson and Paul Kruger), though they held very different political convictions, were united in their belief that the volkstem was the sovereign voice (de Koningstem) and that ultimate sovereignty resided in the people. ${ }^{49}$ Inspired by John Austin, John Kotzé's view was that supreme (sovereign) power attached, not to the people, but to the Volksraad, that the people had moral sanction only over the Volksraad and that the Volksraad could therefore not be dictated to by the views of the people expressed in the Grondwet. Only later, when it became apparent to Kotzé that his judgement in McCorkindale had created the political conditions for the unbridled use of power to achieve ends by means more despotic than democratic, did he readjust his thinking and appeal to the volkstem as the definitive sovereign voice.

At the time, though, he sought rather for additional authority to shore up his view that the Volksraad was, in a very real sense, above the law. He found it in a judgement of the Cape Supreme Court, handed down in 1864. In compiling the first edition of the published law reports of the South African Republic (the industrious Kotzé had prepared the judgements himself (and translated them from the original Dutch), he inserted a footnote at the end of his judgement in McCorkindale. It was a reference to a decision of the Cape Supreme Court, decided in 1864, but only published in 1885, namely Dean and Johnson $v$ Field, ${ }^{50}$ a decision that supported the line he had taken in his own judgement.

In that case the Cape customs authorities had refused to release goods, stored in the customs shed at Cape Town harbour, until the owners had paid the required customs duties and, importantly, until they had also signed a guarantee to pay such increased duties as the Cape Legislative Assembly would pass at its next session. The owners refused to sign the guarantee, their goods were not released and they then sought a court order to enforce delivery. At an initial hearing, the court expressed the view that the arrangement was unjust and that the Legislative Assembly would reconsider their approach. The court's view was disregarded and an act was passed that increased the customs duties and indemnified the customs authorities from damages for actions such as those undertaken by the customs authorities. The court, at its second hearing, found that they were faced with a fait accompli. Whatever the injustice of the matter - legislating ex post facto and doing so in respect of a pending matter - as long as the formal requirements for law-making had been met, the provisions were law and the court was bound by the provisions and "utterly

49 See the discussion in Van der Merwe 2017a: 161-163. This same view was expressed in writing in 1884 , only four months before the McCorkindale judgement, in an editorial in the first edition of the De Republikein newspaper of 8 Aug 1884. In a true republic (like that of the ZAR), he wrote, the people had the government of the state in its hands, the legitimate voice of the people was heard and acted upon. See Kleynhans 1966: 23.

50 (1885) 1 Roscoe Reports 165 at 165-178. 
powerless" ${ }^{51}$ to change the law. Whatever the court's views on the justice of the matter, wrote Bell J, an order that would bring the judiciary into conflict with the executive would be "a state of affairs which every wise and prudent person would, on reflection, exceedingly lament". ${ }^{52}$ Kotzé CJ found himself in good judicial company and must have taken solace from it.

\section{The Nellmapius Affair of 1885-1886}

By 1885 Hugo Nellmapius was a man of great influence, an owner of many concessions, a facilitator of the purchase and sale of many concessions and an esteemed consultant to Paul Kruger and his executive on commercial opportunities in the Republic. ${ }^{53}$ However, he was also financially stretched. Three years earlier he had ceded his concession to manufacture gunpowder and ammunition in the ZAR to Samuel Marks and Isaac Lewis, themselves influential confidants of Paul Kruger and his executive. ${ }^{54}$ They had established a London-based company, the South African Pioneer Powder Factory. In terms of the concession arrangement, the government had a 25 per cent shareholding in the company. Nellmapius was the manager of its affairs in South Africa. A London representative of the company, sent to Pretoria to investigate its business interests, found evidence that Nellmapius had embezzled the company out of $£ 3500$ and laid a charge of fraud against him in September 1885. Willem Leyds, the young Hollander appointed as state attorney in August 1884 after Kruger's visit to the Netherlands, conducted a preliminary investigation and found sufficient evidence to justify Nellmapius's prosecution. The government and its business associates were alarmed. State Secretary Bok, who represented the government on the board of the company, made representations to Leyds to drop the charges; Isaac Lewis wrote to the Executive Council on behalf of the directors of the company, intimating that the directors wished for the charges to be dropped; the Executive Council wrote to Leyds and informed him that it would be in the interests of the government if the charges were dropped; and Kruger himself spoke to his young protégé.

Leyds, though, was made of stern stuff. Although it took a full year after the charges had initially been laid, Leyds eventually prosecuted Nellmapius before Judge Brand and a nine-man jury in September 1886. Nellmapius was found guilty of theft by means of embezzlement and sentenced to eighteen months' hard labour.

51 At 171 of Bell J's judgment in Dean and Johnson v Field.

52 Idem 172. Bell J quoted with approval (at 173) from Sir Edward Coke's Institutes of the Lawes of England of 1628 that "it was possible for the Parliament to make an Act which was illegal by being contrary to natural justice, but which yet would be law, because the authorities and the subject would be bound to give effect to it".

53 On what follows, see Kaye 1978: 50-52. See, too, Van Niekerk 1985: 34-37.

54 On Marks and Lewis and their influence on Paul Kruger, see Nathan 1941: 187-188 and 313. See, too, Wheatcroft 1986: 69-70 and 86. 
His conviction and the heavy sentence imposed were sensationalised by the local press.

Nellmapius appealed against the finding and the sentence. Brand $\mathrm{J}$ gave leave to appeal and reserved six points of law for the consideration of the full bench of the Supreme Court. Injudiciously, as it turned out, he refused Nellmapius' request to be released on bail pending the hearing of the appeal. This refusal set in train a quite remarkable series of events, avidly reported on by the press, representing both proand anti-Nellmapius views. ${ }^{55}$

Nellmapius petitioned the State President and his Executive Council on the following day for a full pardon. Article 83 of the Grondwet prescribed the conditions under which a petition for a pardon could be considered, namely only after it had received the advice of the sentencing court on the matter. ${ }^{56}$ State Secretary Bok duly wrote to Judge Brand on that same morning, requesting his "urgent" advice on the matter; he wrote to him again later that afternoon when the judge had still not responded to the "extremely urgent" note. Brand played a waiting game: he replied only the next day, expressing his surprise that the petition itself had not been sent to him and that his opinion was being sought on a matter that was sub judice. Brand received the petition almost immediately and a further request to have his advice ready by the time the executive met that afternoon.

Brand, not having the benefit of Kotzé's collegial advice (the latter being on circuit) went to see Kruger. Kruger told him in no uncertain terms that he expected him, at the very least, to release Nellmapius on bail pending the appeal. Brand refused and on the next day he returned the petition with a note indicating that the matter was out of his hands. Bok's response was to write a note to Brand indicating that Nellmapius had withdrawn all six points reserved for appeal, which, in effect, meant that the matter was no longer sub judice. He had instructed the messenger to await the judge's advice. Again Brand waited until the following day before he replied. The executive, he wrote, continues to interfere in an ongoing legal process (withdrawal of the appeal is therefore not the end of the matter), which it has no authority to do.

Yet again Bok wrote to Brand. The executive has resolved to grant Nellmapius a pardon, having consulted State Attorney Leyds (who, it must be said, advised neither for nor against the pardon, merely indicating that he thought it premature). A sentence had been pronounced, everything possible had been done to secure advice from the sentencing judge and the legal process (the appeal) could still run its course; therefore the constitutional provisions had been complied with. Brand then resigned his position as a judge, informing Bok that as an independent judge and a man of honour, he could not accept the executive interference in the judicial process. The

55 On the following, see Kotzé 1941: 87-107. See, further, the note to the published judgement of State v Nellmapius (1886) 2 SAR 121 at 133-134; Kaye 1978: 52-54; and Van Niekerk 1985: 37. 56 See Jeppe \& Kotzé 1887: 45. 
executive, of course, readily accepted Brand's resignation. At no stage did Kruger seek an audience with Brand, nor even with the Chief Justice, on circuit in Heidelberg at the time. It spoke volumes about his attitude towards the presidency and the exercise of his executive powers. On 8 October 1886 Nellmapius was released from prison.

In the meantime, Chief Justice Kotzé had returned to Pretoria (on 6 October), having heard of the judicial/executive stand-off. He met with Brand, read the correspondence and decided that Brand had acted appropriately. The validity of the conviction and sentence was still subject to judicial scrutiny, even if the points of appeal had been withdrawn. The pardon was premature, an interference in the judicial process and therefore unconstitutional. To his credit, Kotzé then acted with the courage of his convictions, amid the swirl of press-inflamed public opinion. $\mathrm{He}$ had Nellmapius rearrested on the strength of the original warrant of arrest. He also wrote to State President Kruger, informing him of his view that the independence of the judiciary had been unduly interfered with. Petitions did the rounds, either in support of Kotzé and the judiciary or of Kruger and his executive.

Kruger called for a special sitting of the Executive Council. The councillors were in a belligerent mood, some calling for Kotzé's dismissal. Kruger, increasingly reliant on Leyds's advice, approved a letter from the executive to Kotzé with Leyds's input. It repudiated Kotzé's view and confirmed its own view, namely that no interference with the judiciary had taken place. It chastised Kotzé for the rearrest of Nellmapius without even consulting the government on the matter. It further informed him that the executive decision was that it would acquiesce in the rearrest of Nellmapius and would allow the appeal to run its course; however, the magistrate (landdrost) of Pretoria had already been instructed to release Nellmapius upon conclusion of the appeal, on the basis of the pardon that had already been issued. In other words, the law would be allowed to run its arcane and inconsequential course, but the executive would have its way regardless.

Prudently, Kotzé did not immediately respond to the executive notification. He first needed to populate a denuded Bench. Burgers had resigned in July 1886 and had been replaced on 1 August by the charismatic twenty-seven-year old Ewald Esselen. ${ }^{57}$ Esselen, while a medical student at the University of Edinburgh, had served as secretary/interpreter to the ZAR delegation that had negotiated the London Convention in 1883 (he was also an ambulance driver for the Boer forces in the 1880-1881 war), had studied law in London and practised as an advocate in Cape Town before coming to the $Z A R$ in 1886. SG Jorissen, son of EJP Jorissen and sonin-law of the former president, Thomas Burgers, was appointed to replace Brand in October 1886, in the midst of the Nellmapius affair. He died in $1889 .{ }^{58}$ EJP Jorissen

57 Esselen was born in 1858 and died in 1918. On his fascinating career as judge, advocate and progressive politician in the ZAR, see Van der Merwe 1984: passim. See, too, Roberts 1942: 352 (on Burgers's resignation) and 358-359 (on Esselen's appointment and his subsequent career); Van Onselen 2017: 232-236.

58 See Roberts 1942: 366. 
was permanently appointed as a judge in the Supreme Court of the $Z A R$ in 1889 , a year after his son's death. ${ }^{59}$

Kotzé sought advice on how to deal with the judicial-executive stand-off beyond the republic's borders. Sir Henry de Villiers, Chief Justice of the Cape Supreme Court and a regular correspondent of Kotzé's, advised him ${ }^{60}$ that in his view the rearrest of Nellmapius was invalid and that, as the six points of law reserved for appeal had been withdrawn by the appellant, the appeal had effectively been withdrawn. Kotzé, together with Esselen and SG Jorissen, pondered this and other advice. They eventually rejected the advice. In a lengthy letter to State President Kruger on 17 November 1886, some six weeks later, ${ }^{61}$ they informed the executive that it had interfered with the independence of the judiciary. The sentence pronounced by Brand $\mathrm{J}$ was not final - it was still subject to appeal; the withdrawal by the defence of their appeal was not an end to the matter, as the court itself had ordered the six points of law to be argued before a full bench and only the court could vary that order, having heard argument. They further pointed out that the rearrest of Nellmapius merely placed him in the position he was in after sentence had been passed, his rights were not impaired; granting a pardon pending an appeal was premature and amounted to a conditional pardon, for which the Grondwet made no provision. The executive reply of 19 November was brief: we stand by our opinion; let judicial events take their course. ${ }^{62}$

The appeal was heard in November 1886 by Kotzé CJ, Esselen J and Jorissen J and judgement (written by Kotzé CJ) was handed down on 24 December $1886 .{ }^{63}$ The court dismissed five of the six points of law reserved for appeal, but upheld the sixth point. It concerned the question whether the preliminary investigation conducted in October 1885 had been procedurally flawed. The prosecutor had been absent for the first two days, so the landdrost himself acted as prosecutor in this period. The defence argued that this failure to observe the distinction between judicial officer and prosecuting authority not only contravened the 1864 Criminal Procedure Ordinance, ${ }^{64}$ but fatally contaminated the evidence presented at the trial. This was because the individual whose evidence had been taken down in the first two days had died and had therefore not testified in person at the trial. The trial court should not have admitted the improperly obtained evidence; once admitted, it contaminated the whole of the evidence, particularly since a lay jury could not be expected to discriminate between that evidence and the rest of the (properly obtained) evidence. "The fountain of justice," wrote Kotzé CJ, "must remain pure and unpolluted, and this can alone be ensured by a strict observance of the provisions of the law". ${ }^{65}$ The

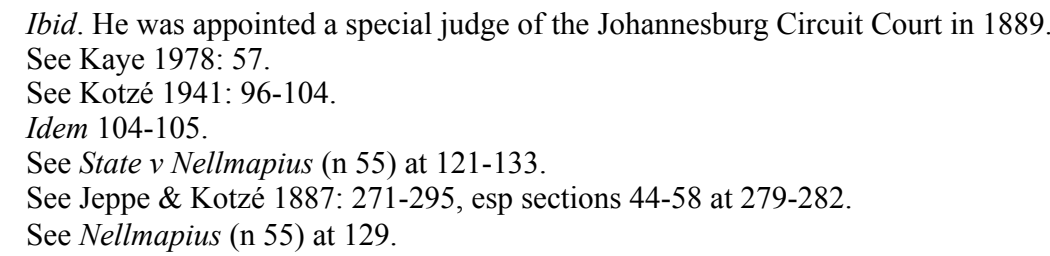


conviction, therefore, was set aside. Kotzé CJ was at pains to point out that the court had not found that no crime had been committed, merely that the trial court should not have found Nellmapius guilty on the evidence presented to it. ${ }^{66}$

It is difficult to escape the conclusion that the result of the appeal was contrived, that the politics of appeasement trumped a search for justice, pure and simple. Kotzé faced a political dilemma. It would have been feasible to argue (as State Attorney Leyds forcibly did) that the improperly obtained evidence should have been struck from the record and the rest of the evidence subjected to scrutiny, rather than to assume that all of the evidence had been contaminated. Kotzé CJ (and his brother judges) chose, however, to adopt an approach satisfactory to all parties. The course of justice ran its full course. Nellmapius, if not actually found guilty of a crime, was made to understand in no uncertain terms that he could count himself very lucky not to have served a prison sentence; the executive could take comfort from the fact that their close business associate had not in fact been found guilty of any wrongdoing (thus exposing some less than salubrious business practices acquiesced in by the government) and that the court's quashing of the conviction was a victory for the executive who would not be dictated to by the judiciary. As in the McCorkindale matter, Kotzé wanted to signal his commitment to judicial independence and judicial integrity, but to do so in a manner that did not create a rift between the strongwilled, powerful Paul Kruger and his government and a young, inexperienced and vulnerable judiciary. This soft approach adopted by Kotzé would harden considerably in the years ahead and precipitate open conflict between state president and chief justice some ten years later. It was an approach that did not endear him to Leyds; the latter was convinced that Kotzé had acted in a cowardly fashion and that political manipulation underpinned the judgement. ${ }^{67}$

Christoffel Brand continued to practice law, but with no great success. He was "not a man of temperate habits" and his stand against executive interference was "the one great episode in [his] life" ${ }^{68}$ Nellmapius continued to serve as the government's business consultant and to be the recipient of governmental concessions-based largesse. With the discovery of the vast riches of the Witwatersrand gold-bearing reef in May 1886, he became a valuable interlocutor between the mining magnates and the government. He established a farming enterprise south of Pretoria, called Irene (named after his eldest daughter) that became a byword for agricultural acumen and innovation. He never became better at business, however, and his influence waned in later years. When he died in 1893, aged forty-six, he was insolvent.

66 Idem 132.

67 See Van Niekerk 1985: 38; see, also, Kaye 1978: 58-59.

68 The two quotes are from Nathan 1932: 14 and Nathan 1941: 239 respectively. On Brand see, too, Cohen 1976: 117-119. 


\section{$4 \quad$ Trustees in the Insolvent Estate of Theodore Doms $v$ Bok NO (1887) 2 SAR 189}

\section{The discovery of the Witwatersrand goldfields in 1886}

While a political storm brewed over Pretoria in the latter months of 1886 when the Nellmapius affair played itself out, a very different and far greater storm was brewing some sixty kilometres south of Pretoria. In May of that year, George Harrison and George Walker, while doing odd-jobs for the widow Oosthuizen on her farm Langlaagte on the eastern edges of the Witwatersrand, discovered gold in the rocky outcrop on her farm. It was soon confirmed to be a section of a massive gold-bearing reef that ran for 100 kilometres east to west. It was the biggest discovery of gold in the country, dwarfing into insignificance the goldfields of Lydenburg and Barberton. In the coming years it would prove to be the richest goldfield ever discovered anywhere on earth. ${ }^{69}$ Within weeks, hundreds, and then thousands, of foreign fortune-seekers (the "uitlanders") and also Boers had swamped the Witwatersrand, lured by the promise of untold riches. By September 1886 the Witwatersrand had been declared a public digging and by October the township of Johannesburg had been proclaimed.

It soon became clear that the political and economic landscape of the South African Republic, in fact of the entire southern African region, would be transformed by the vast riches to be had on the Witwatersrand. It was not only individual fortune-seekers who flocked to the Witwatersrand, most of whom would be bitterly disappointed when it became clear that significant capital would be needed to mine for the gold. Rich and influential businessmen, who had become rich as a result of Kimberley diamond mining, made their way to the Witwatersrand (some via Barberton): men like JB Robinson (younger brother of William Robinson), Cecil Rhodes, Alfred Beit, Julius Wernher, Abe Bailey, Barney Barnato, Hermann Eckstein, Samuel Marks and Isaac Lewis. ${ }^{70}$ It was to their commercial enterprise and business acumen that the Witwatersrand goldfields owed its massive wealth-generation.

Inevitably, the diggers soon organised themselves into a representative committee and met with State President Kruger in February 1887 to discuss with him the many socio-economic grievances they had already built up against the republican government a mere six months after they had established themselves on the "Rand". The uitlanders' (most of whom were British or British-colonial) sense of grievance against the Boer government never dissipated, nor did Kruger and his government's

69 A plethora of publications exist on the early years of the discovery of the Witwatersrand goldfields and the establishment of Johannesburg in the late 1880s. I consulted primarily the following sources for general information: Cartwright 1965: 1-84; Wheatcroft 1986: 86-91 and 111-123; Meredith 2007: 176-193; and Davenport 2013: 145-182.

70 The best discussion of these men - the Randlords - and their times remains that of Wheatcroft 1985: 92-195. 
antipathy towards the alien and deeply intrusive influence on their chosen lifestyle lessen over time.

The establishment, on the doorstep, as it were, of the republican capital, of an uitlander-dominated mining colossus, producing unimagined wealth and mushrooming by the month, could not but influence the characters of the two personalities that would ultimately clash head-on in the late 1890s over the Brown v Leyds judgement.

Paul Kruger, the archetypal Boer, had a political and religious mind-set that belonged to the early nineteenth, rather than the late nineteenth century: his mistrust of the so-called English was deeply ingrained, as was his desire to maintain the old ways of the Boers against foreign intrusion; and his faith in the Almighty's divine purpose for his volk and their divine right to determine their own destiny remained unshakeable. He sought, and found in the person of WJ Leyds in particular, Dutch political and cultural protection from the Johannesburg foreigners and it was to the Netherlands and Germany that he looked to strengthen his government, the administration of the state and civil society. ${ }^{71}$

John Kotzé, Cape Dutch born and bred, educated in England, married to an Englishwoman, and thus an avowed Anglophile, had not Kruger's antipathy towards the British uitlanders. He was no radical and, empathetic towards the Boers and their struggle for survival and recognition, inclined towards a closer political union between the English, the Cape Dutch and the Boers in southern Africa. He was resistant to the narrow sectarian politics practised by Kruger and to the strong influence the Dutch bourgeoisie class had over Kruger. ${ }^{72}$ It also made him consider carefully the jurisprudential carte blanche he had given the Kruger government and the Volksraad in McCorkindale and the soft approach he had adopted towards executive overreach in Nellmapius.

\section{John Kotzé begins his jurisprudential swerve in Doms}

Theodore Doms, agent extraordinaire, died in $1886 .{ }^{73} \mathrm{He}$ died insolvent. The trustees of his insolvent estate claimed from the state twenty-one farms on the Harts River in the Bloemhof district, said to have been promised to him by the late president Thomas Burgers in 1874 for services rendered by him to the state. Doms had, just prior to his death, asked the Volksraad to transfer the farms into his name. The Volksraad passed a resolution in August repudiating Doms's claim to the farms. In April 1887 the trustees again demanded the transfer of the farms and again the Volksraad refused. When summons was issued against it for the transfer of the farms, the Volksraad

71 See, eg, the character sketch by Marais 1961: 5-11.

72 This thumbnail sketch of his character is based on the views expressed by him in his memoirs: see Kotzé 1934: passim, and Kotzé 1941: passim.

73 On Doms's chequered career, see Van der Merwe 2017b: 145-147. 
again passed a resolution, in May 1887, that Doms's estate had no claim to any farms and that the resolution was their final decision on the matter. ${ }^{74}$

Law agent Auret then instituted an action against the government for the transfer of the twenty-one farms. The matter was heard in August before a full bench of the Supreme Court (Kotzé CJ, Esselen J and Jorissen J) and judgements were handed down (by all three judges) on 24 December 1887 (the day before Christmas, as had also happened in Nellmapius a year earlier). ${ }^{75}$

Kotzé CJ found himself unable to depart from his judgement in McCorkindale. ${ }^{76}$ He did, however, praise Auret for the "very able manner" in which he had argued that Volksraad resolutions did not meet the requirements for law-making of article 12 of the Grondwet and therefore did not have the force of law. He also wrote that "I will gladly admit that it is desirable, yes, necessary, that our Constitution should be revised" to insert a provision "of the greatest importance" that would give a court the authority to test whether a law or resolution passed the test of "constitutionalism". His judicial duty, however, was to apply the law as he found it and not to make the law that in his opinion most benefitted society.

In McCorkindale his view had been that American constitutional jurisprudence that allowed the US Supreme Court to test the constitutionality (and therefore validity) of laws passed by Congress, was a desirable state of affairs, but unachievable, because the federalist state structure of the USA meant that a supra-norm like a constitution was needed to regulate the activities of Congress (thus John Austin). Now, in Doms, it had become "necessary" for the court to be given a testing right, this despite the fact that the ZAR (like Great Britain and the Netherlands) did not have a federalist structure.

Esselen J concurred with "the Chief" in a brief judgement. ${ }^{77} \mathrm{He}$ "perfectly" agreed with Kotzé CJ's McCorkindale judgement. It was clear, he wrote, that "the people [volk] have given the Volksraad the fullest power to make laws as it thinks fit, and that it was never the intention of the people or the Volksraad that the High Court should have the power to test those laws according to the Constitution". It was desirable that change should be effected, but this could only be done by the volk and the Volksraad, not the court. Esselen J correctly (and contrary to Kotzé CJ's approach in McCorkindale) emphasised that the volk was the source of the Volksraad's supreme authority to make laws and that its intent, expressed in the Grondwet, was that the court should not have a testing right. Framed differently: "[T] he people have the King's voice," in a legal and not only a moral sense (the view espoused by Kotzé CJ in McCorkindale).

74 On this background to the judicial proceedings, see Trustees in the Insolvent Estate of Theodore Doms v Bok NO (1887) 2 SAR 189 at 189-191.

75 Idem 189-204.

76 Idem 191.

77 Idem 192. 
Jorissen J, bravely, wrote a dissenting judgement, ${ }^{78}$ one that would later influence Kotzé CJ's own approach to no small extent. He had appeared for the executors of McCorkindale's estate in 1884 and now had the opportunity to express his judicial opinion on the validity of Volksraad resolutions. He wrote a lengthy judgement, not in all respects a model of clarity, that was in the nature of a careful analysis and considered refutation of Kotzé CJ's judgement in McCorkindale.

Clearly, he wrote, the Volksraad had the power to amend the Grondwet, and had often done so, even though no special procedure existed for this to happen. This did not mean that the Volksraad was above the Grondwet (as McCorkindale would have it). This much was clear from the oath of office of Volksraad members, in terms of which a member swore that he would conduct himself in accordance with the Grondwet. ${ }^{79}$ It might be that, in terms of historical fact, the Volksraad "created" the Grondwet, although "the driving force" behind it was in fact the combined military councils of MW Pretorius and Stephanus Schoeman, convened to engineer approval of a Grondwet in February $1858 .^{80}$ This did not mean, however, that the Volksraad was above the Grondwet, as the Grondwet in fact determined, if not its actual existence, then its manner of functioning. ${ }^{81}$

In McCorkindale, Kotzé CJ had cited John Austin as authority for the view that the sovereign power possessed by the Volksraad could not be subject to legal limitations as a limitation of highest authority or sovereign power was, scientifically speaking, a contradiction in terms. In Doms, SG Jorissen J cited the Swiss-German international and constitutional lawyer, Johan Bluntschli, ${ }^{82}$ as authority for his contention that sovereign power can indeed be limited in law. Sovereign power is not the same as absolute power. ${ }^{83}$ "Sovereignty" meant independence from any higher state authority; it did not mean an arbitrary renunciation of its obligations to other states and to the protection of the individual or civil liberties enjoyed by humanity in general. The independence inherent in sovereignty must be understood in a relative sense - relative to the context within which that sovereignty is exercised, namely the foundational principles of international law and of the civil rights of individuals and organisations. ${ }^{84}$

Once it is recognised that sovereign power is a relative concept, it becomes possible to understand the sovereign power exercised in the Volksraad by the representatives or mandatories of the people within the context of the Grondwet, that is, by virtue of the Grondwet and in accordance with its provisions. ${ }^{85}$ Therefore, the

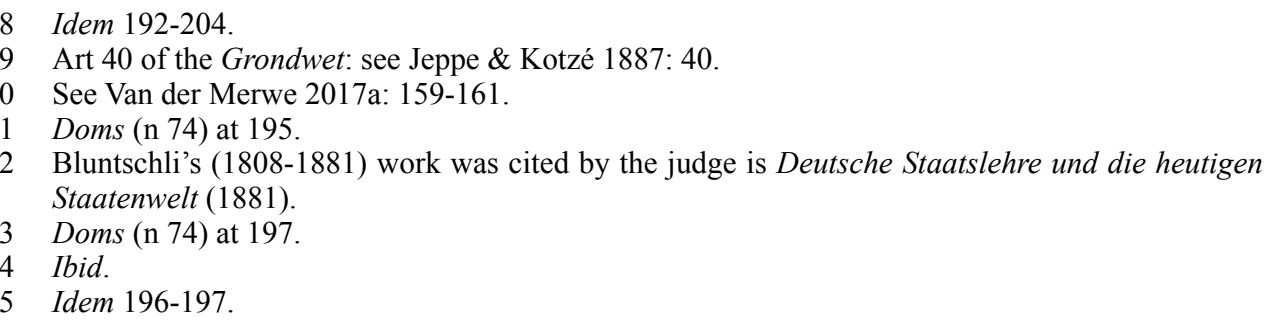


constitutionally ordained power the Volksraad indubitably has to alter the Grondwet (to change the way in which it reveals or expresses its legislative will) must originate from the Grondwet.

An expression of legislative will - a law - is, in the language of John Austin, a command given by a competent authority, which those subject to that authority are obliged to obey. ${ }^{86}$ However, it is important to note that there are two types of commands (thus Austin): those that have general application, and those that have particular application only. The former are laws or rules properly so-called, the latter are occasional or particular commands, not laws. They are in the nature of what in Roman and Roman-Dutch law are called rescripts, particular dispensations granted by a sovereign to individuals, susceptible to judicial review only if they caused prejudice to third parties. ${ }^{87}$

A Volksraad resolution was in the nature of an occasional or particular command. The resolutions routinely passed by the Volksraad were primarily in the nature of responses to particular sets of circumstances presented to it for consideration and decision. These resolutions were passed on the basis of the powers granted to the Volksraad by the Grondwet, and were in addition to its power to make laws. Resolutions, for the most part, ${ }^{88}$ had binding administrative force in respect of the government (the executive), but they did not and could not bind judges, as they did not have general application. The resolution in the instant case was not a law, as it did not comply with the law-making requirements prescribed in the Grondwet. It was a special resolution passed in favour of the government to deprive a private subject of its right to have its case decided by the court. This it could not do, as it did not have judicial power and could not act as a judge in its own cause. ${ }^{89}$

At the very end of 1887, therefore, when judgement in Doms was handed down, one finds the Chief Justice still clear in his own mind that a court cannot as of right challenge the validity of laws passed by the sovereign legislature. However, he is now of the view that it was not only desirable, but indeed necessary, in the dramatically changed socio-economic conditions of the country, that the Supreme Court should have the right to determine the constitutional validity of laws passed by the Volksraad. Judge Jorissen had also presented a judicial case for a declaration of invalidity of the legislative activity of the sovereign legislature. At his weekly meetings with State President Kruger ${ }^{90}$ Kotzé would surely have mentioned the need

86 See, for what follows, idem 197-199.

87 Jorissen J consulted the Codex of Justinian; Van Leeuwen's Het Rooms-Hollands-Regt (1664); Savigny's System des heutigen römischen Rechts (1840-1849); and the Utrechtsche Consultatien (1676-1700) as authority for his discussion of the legal status of rescripts.

88 Some resolutions, though called thus, were in reality laws, as they had been proposed, discussed and published in a manner that was prescribed for law-making: see Doms (n 74) at 202.

89 Idem 203-204.

90 See Kotzé 1941: 126. 
for a review of the Constitution to allow for a judicial testing right. Kruger would have noted the Chief Justice's views with concern.

\section{The winds of change blow in the ZAR and Paul Kruger's and John Kotzé's political attitudes harden}

\section{Introduction}

Already by 1888 , when John Kotzé's jurisprudential conversion was underway, the Witwatersrand goldfields had proven themselves to be the source of spectacular wealth for the privileged few, a source of income and of unbridled speculation for thousands, and a means to scrape a living for many thousands more. ${ }^{91}$ Large, capital-intensive, expertise-rich mining companies had absorbed the scores of small, inefficient companies formed early on and decisions taken by their directors and financiers directly influenced the lives of many. Most influential of all was Hermann Eckstein and Co (colloquially called "the Corner House") - who represented London-based Wernher, Beit and Co - and Cecil Rhodes's Consolidated Goldfields. For a period in the early 1890 s, a serious depression set in, when mining had to "go deep". Once new and sophisticated mining techniques had been developed and implemented to extract the gold from the ore deep in the bowels of the earth, Alfred Beit established the biggest mining company of all, Rand Mines Ltd. The boom then continued and the Witwatersrand was truly the "richest spot on earth". ${ }^{92}$ The enormous wealth controlled by the directors of the large mining houses (who came to be referred to as the "Randlords") gave the latter political as well as economic influence. This they often used against Kruger and his government, particularly in respect of the deleterious effects of the monopolistic concessions policy employed by Kruger. Enduring sources of contention were that they were forced to buy poorquality dynamite at inflated prices from overtly corrupt men, such as Edouard Lippert, Alfred Beit's cousin, and the difficulties in seeking to secure a constant and cheap supply of African labour to the mines. Keeping costs as low as possible was a massive problem in mining a commodity with a fixed international value.

The income generated by gold production was a valuable source of revenue (through taxes, licence fees and levies) for a perennially cash-strapped Boer government. It, and the multitude of businesses and industries it spawned, also, however, led to a burgeoning parallel economy that dwarfed and threatened the primarily agriculture- and concessions-based formal economy. The mining and

91 Of the many sources in this regard, see the following accessible overviews provided by Cartwright 1965: 85-133; Wheatcroft 1986: 120-137; Meredith 2007: 291-310; Davenport 2013: 175-182 and 225-237.

92 By the end of 1893 some two-thirds of the gold mining companies had collectively produced more than $40000 \mathrm{~kg}$ of gold at a value of $£ 52 \mathrm{~m}$ (roughly $£ 500 \mathrm{~m}$ in today's monetary values: see Van der Merwe 2015: ix-x). See, further, Davenport 2013: 232. 
related industries also introduced into the $Z A R$ cultural and social attitudes, activities and appetites (both elevating and sordid) that was alien to the Boer psyche. ${ }^{93}$ Most importantly, from a political perspective, the foreigners (uitlanders) - mostly British - who lived in and around Johannesburg and whose numbers continued to grow, posed a numerical threat to the Boer citizens of the $Z A R \cdot{ }^{94}$

These uitlanders, recognising their potential politico-economic dominance over the Boers and unwilling to have their lives and livelihoods determined by a class of people to whom they felt themselves superior in every way, organised themselves into lobby groups and were increasingly strident in voicing their grievances against Kruger and his government. Their grievances were varied and included some of the following: not enough political representation in the corridors of power; a too heavy tax burden; not enough cheap labour; insufficient resources spent on improving living and working conditions on and around the mines; inadequate educational facilities; and Dutch as official language at the expense of English.

Paul Kruger and his government had their own grievances: the uitlanders were foreigners, earning good money, not because they had a right to do so, but because the Boer government allowed them to; their lifestyles were alien to, intrusive upon and in some instances an open affront to the sedate, Bible-governed lifestyles chosen by the Boers and jealously guarded by them; they were predominantly British and therefore in the eyes of the Boers inherently untrustworthy; Great Britain had begun to exhibit an uncomfortably close interest in the goldfields and in the territories surrounding the $Z A R$; and, not least, there were too many of them, ${ }^{95}$ they were greedy, loud and brash and they complained too much and too often. ${ }^{96}$ Great Britain was beginning to cast an ominous imperial shadow over republican affairs.

In May 1888 the second presidential election took place. Paul Kruger accumulated 85 per cent of the vote and comfortably beat his opponent, Commandant-General Piet Joubert. ${ }^{97}$ Kruger's political mantra had always been, was then and would always be, the safe-guarding of the independence of the republic and of his people. Their voice, their volkstem, would not be silenced, it would remain sovereign. It was his single, dominant concern and he perceived, already in 1888, that the goldfields of

93 In 1895 there were ninety-seven brothels in Johannesburg. Olive Schreiner famously called Johannesburg (in 1898) "a great, fiendish hell of a city" and Kruger called it "duivelstad" (devil's town). See Meredith 2007: 293.

94 There are no reliable census statistics for these years. Paul Kruger opposed any form of counting of people as unbiblical: see Kotzé 1941: 126.

95 See, eg, Marais 1961: 1-3. Undoubtedly white, male uitlanders would soon become numerically dominant as opposed to the enfranchised Boers.

96 When, in March 1890, Kruger addressed a group of disgruntled uitlanders in Johannesburg who was clamouring for economic reforms, he was said to have addressed them as "burghers, friends, murderers, thieves and robbers": see Nathan 1941: 265-267; and see, further, Kotzé 1934: 112113.

97 See Nathan 1941: 241-242. 
the Rand and the men it attracted would be the most dangerous threat to his cherished independence.

In June of that year Kruger had WJ Leyds, then state attorney, appointed as state secretary, the second-most powerful position in the republic and also responsible for foreign affairs. ${ }^{98}$ Henceforth the coarse, wily old Boer and the refined, sharp, hardworking young Hollander would work very closely together. They made a formidable pair, ${ }^{99}$ and seldom did the Executive Council and the Volksraad take decisions not decisively influenced by them. To his own cost, John Kotzé would find out just how formidable a pair they were politically.

\section{The uitlander presence triggers differing conceptions of people's sovereignty by Kruger and Kotzé}

State President Kruger's attitude towards the political threat posed by the uitlanders of Johannesburg and the Rand was based on a simple political philosophy. In the Zuid-Afrikaansche Republiek the volk (the people) had the King's voice; their voice and theirs alone was sovereign. It had been the dominant political creed among the Boers since they first organised themselves politically in the trans-Vaal area and underpinned the 1858 Grondwet. ${ }^{100}$ Paul Kruger, deeply immersed in Boer politics from early on, had adopted this creed since he first made himself available for high office in $1877 .{ }^{101}$ When he accepted the leadership of the triumvirate on the eve of the first Anglo-Boer War of 1880/1881, he attributed the divine authority of God to the sovereign volkstem (the voice of the people). ${ }^{102}$ So, in effect, the statements in articles 12 and 29 of the Grondwet, namely that the Volksraad was the highest authority in the state, meant that it exercised that authority as a result of the sovereign will of the people, who in turn were granted such sovereignty by the grace of God - whatever contrary views Kotzé CJ expressed in McCorkindale (and Doms).

Kruger introduced a new strand into this political philosophy in the 1880 s, no doubt strengthened in his convictions by the uitlander threat to the volk's sovereignty. When engaging in debates in the Volksraad, he often cautioned the members not to vote in favour of a matter if there was uncertainty whether the volk would approve. Rather delay adoption of a particular measure until the Volksraad members had gained the unquestioning support of their constituents for the measure. This was so even if the representatives themselves supported the measure and even if the benefit

98 See Van Niekerk 1985: 60 and 63-64.

99 Eugène Marais, editor of the progressive newspaper, Land en Volk, wrote in 1892 that Leyds was the "left-right hand and head of Kruger": see Van Niekerk 1985: 61.

100 See the discussion in the first article of this series: Van der Merwe 2017a: 131-138, 143-145 and 162-164.

101 See the discussion in the second article of this series: Van der Merwe 2017b: 155.

102 Idem 163-164. 
for the public was palpable. ${ }^{103}$ Public sentiment must trump Volksraad deliberations: the public was King and its representatives were merely their servants. ${ }^{104}$ The most complete statement of his conviction on this matter of volk sovereignty is contained in an address to the Volksraad in June 1889. He said the following (translated from the original Dutch) in respect of the proposed construction of certain railway links around the Witwatersrand: ${ }^{105}$

[I]f the goldfields were to suffer a setback the whole country suffers a setback. If, notwithstanding all the advantages, the public countrywide remained opposed to the matter, it must, however, not be pursued ... Even if the enterprise collapsed, even if the state fell, even if the gravest harm were to follow, we must listen to the volk ... Even if the people were wrong, the government must still obey their voice ... we live in a Republic where the people have the King's voice (we wonen in een Republiek waar het volk de Koningsstem bezit).

Two months later, in August, he would again urge this approach upon a compliant Volksraad. ${ }^{106}$ "The volk", to be sure, was not all of the volk, but the majority; to the majority belonged the koningstem (the King's voice). ${ }^{107}$

This overtly populist approach adopted by Kruger held sway in the Volksraad through the sheer force of his personality and was different from the approach adopted by the founding fathers of the 1858 Grondwet (among whom counted Kruger himself). The Grondwet had been the result of hard-fought political compromise. The premise on which the basic principles of the Grondwet had been founded, was that the people were sovereign; in the exercise of their sovereign will they assigned the highest authority ("hoogste gezag") in the state to their mandatories in the Volksraad; the Volksraad made laws, passed resolutions and held the executive in check on behalf of the people; the people retained their sovereignty over the Volksraad by exercising their right to petition the Volksraad on draft laws that had to be published three months prior to their discussion in the Volksraad, by biennial elections of the Volksraad members and, in practice, by voicing their displeasure at legislative provisions after the fact. The dominant desire was that neither populist sentiment, nor Volksraad authority would dominate, but rather that the Volksraad would exercise its highest authority according to the dictates, not of the raw will of the majority, but of law and justice (wet en regt). ${ }^{108}$

Kruger's populist approach flew in the face of this political compromise. It denuded the Volksraad of its claim to being an assembly of the mandatories of the people, exercising the highest authority in the state subject to certain checks and

103 See Smit 1951: 20-22.

104 He made this comment during the Volksraad session in mid-1887, when the Witwatersrand had already established itself. See, further, Smit 1951: 21.

105 Idem 21-22. See, too, Kleynhans 1966: 23.

106 See Smit 1951: 20-21.

107 Idem 22-24, 125-126, 128-130 and 135-136. See, also, Kleynhans 1966: 26.

108 See the discussion in Van der Merwe 2017a: 158-164; and Van der Merwe 2017b: 129-135. 
balances. In effect, it demanded from the Volksraad that its legislative deliberations should not be guided by, but be determined by, the majority voice of the people (extracted from regular constituency consultation).

It seems reasonable to conclude that this deeply conservative, protectionist approach by Kruger was informed (if not wholly, then substantially so) by his desire to preserve the independence of the people's republic at all costs from the uitlander threat - even at the expense of efficiency and progress. ${ }^{109}$ The volk's full participation in affairs of state (impractical, forced, uninformed, unnuanced and abuse-rich though it was) could erect a bulwark against outside influence. It also allowed him and his supporters to invoke the divinely supported volkswil (will of the people) when it suited them, knowing full well that there was no constitutional means to accurately and regularly gauge popular sentiment on a particular matter. It became a useful political tool.

Chief Justice Kotzé was well aware of this and strove to impart his own particular conception of the people and their exercise of the sovereign will. At the opening of Edouard Lippert's cement factory in August 1890, he was called upon to respond to a toast to the Republic's judiciary. The establishment of industries such as the cement factory, he said, was not only to the benefit of the burghers and other inhabitants of the $Z A R$, but would serve to cement(!) all nationalities in South Africa ${ }^{110}$ and realise the hope of one land, one people and one nationality. ${ }^{111}$ This was an expression of political sentiment that was the linear opposite of Kruger's. ${ }^{12}$

\section{Kruger establishes a Second Volksraad in 1890}

At the beginning of the nineties, State President Kruger and his government had serious political and economic issues to concern themselves with. The concessions policy, though frequently refined, remained not only a cornerstone of republican independence, but also a source of friction between the mining magnates and the Boer government. It also spawned widespread corruption in the civil service and among the uitlanders. Uitlander grievances, particularly in respect of the dynamite monopoly, increased, rather than abated. ${ }^{113}$

109 See the comments made by Nathan 1941: 242-248 on Kruger's political approach towards the uitlanders. Manfred Nathan was a contemporary of Kruger and was not unsympathetic towards Kruger.

110 He meant all white nationalities.

111 See Kaye 1978: 63.

112 See, eg, Kotzé 1941: 191.

113 On the dynamite monopoly as a permanent source of major economic and political grievance, see, eg, Marais 1961: 28-33; Wheatcroft 1986: 125-128; Van Niekerk 1985: 124-129; and Meredith 2007: 297-300. 
Kruger would also not budge on calls for the introduction of a customs union and the conduct of free trade between southern African states/colonies. Negotiations between the ZAR government and Great Britain on issues, such as rail links, the establishment of a harbour at Kosi Bay and control over Swaziland, continuously floundered. Any economic foothold for Great Britain in the ZAR was assiduously countered, as it was perceived to be but the overture to political union and the eventual loss of republican independence. ${ }^{114}$

Sustained political pressure from the Rand uitlanders led Kruger to concede on internal political reforms. In 1890 the Grondwet was revised to make provision for amendments to the franchise requirements for $Z A R$ citizenship and for the introduction of a Second Volksraad. ${ }^{115}$

In 1890 the franchise requirements for permanent residents that had been in effect since 1882 had been amended. A white male older than twenty-one years and who was born in the $Z A R$ still had the right to vote. A permanent resident now acquired the right to vote if he had been resident in the $Z A R$ for five years. This meant that large numbers of male uitlanders who resided permanently in the ZAR since 1886, when the Rand gold-rush began, would become citizens and conceivably gain a numerical majority over the indigenous Boers from 1891 onwards. Permanent residents acquired the right to vote only if they had resided in the $Z A R$ for fourteen years and were forty years and older.

In 1890 the Volksraad approved the introduction of a Second Volksraad. The brainchild of Kruger himself, drawn up by Leyds, it had taken Kruger all of his rhetorical skill to persuade the Volksraad to adopt the measure. ${ }^{116}$ Those uitlanders willing to contribute to the wellbeing of the state, but who were not (yet) naturalised citizens, could vote for and become members of the Second Volksraad. To vote for the Second Volksraad, one had to have been a permanent resident for two years and older than twenty-one years. To be a member, one had to have been a permanent resident for four years, older than thirty years and a member of a Protestant church.

In terms of form and process, the Second Volksraad was to be a mirror image of the First Volksraad. Its legislative competence covered a wide range of matters of a broadly economic nature (the competence to regulate the mines and related commercial matters was especially important). The binding authority of laws and resolutions passed by the Second Volksraad was guaranteed. This provision would play an important role in the judicial deliberations in Brown $v$ Leyds some six years later.

The Second Volksraad had no budgetary competence and its legislation could, at the president's discretion, be referred to the First Volksraad for final approval.

114 See, inter alia, Botha 1926: 201-211; Kotzé 1941: 175-192; Marais 1961: 49-52; Van Niekerk 1985: 106-111; and Meredith 2007: 238-243.

115 On the franchise reform and the establishment of the Second Volksraad see, inter alia, Van Oordt 1898: 502-505 and 513-514; Botha 1926: 323-326; Nathan 1941: 267-270; Smit 1951: 131-134; Marais 1961: 53-54; and Van Niekerk 1985: 129-130.

116 See Kotzé 1941: 110-112. 
The latter, therefore, remained the highest authority in the state, it represented the voice of the (majority of the) oude bevolking (the Boers) in whom resided the koningstem. ${ }^{117}$ For this reason the Second Volksraad enjoyed limited legitimacy among Boer and uitlander alike, despite it functioning effectively within its limited scope and providing much-needed legislative oversight over the mining industry. In this, as in other areas, uitlanders continued to feel beholden to a central government and an administrative apparatus that were unable (and often unwilling) to meet their demands. ${ }^{118}$

\section{John Kotzé hoists his political colours to the mast}

One of the biggest beneficiaries of the riches unearthed from the gold mines of the Witwatersrand was the Bench and Bar of the ZAR. John Kotzé himself set the tone. He was co-editor of the massive compilation of all of the laws (and resolutions) of the Republic for the years 1849-1885, De Locale Wetten der Zuid Afrikaansche Republiek; his two-volume translation of Simon van Leeuwen's Het Rooms-Hollands Regt was completed and published in 1886; he edited and translated into English (or had translated) all of the judgements of the republican Supreme Court and had these published as annual law reports from 1886 onwards. He was the dominant judicial personality in the $Z A R$ and soon acquired a reputation in southern Africa for judicial probity and learning, second only to Sir Henry de Villiers, the chief justice of the Cape Colony, with whom he conducted a regular correspondence. ${ }^{119}$

The gold mines led to a huge increase in the judicial workload and the size of the Bench grew with regular appointments of judges well trained in law, either in London or in the Netherlands. Herman Ameshoff and George Morice, who sat with Kotzé in Brown v Leyds, were appointed to the Bench in September 1889 and September 1890 respectively (Ameshoff replaced SG Jorissen who, tragically, died young; Morice replaced Esselen, who resigned to pursue a more lucrative and exciting career at the Bar and to indulge in progressive politics). ${ }^{120}$ From as early as 1887 the Bar increased substantially in numbers, as young Cape-born, London-trained lawyers went to the $Z A R$ to benefit from the huge increase in lucrative litigation brought about by the gold mining and related commercial activities on the Rand. Men such as John Wessels, JS Curlewis and (later) NJ de Wet were members of the Republican Bar in these years. All later became chief justices of the Union of South Africa. ${ }^{21}$

117 See, eg, Van Oordt 1898: 548 and 601; Nathan 1941: 403.

118 See Marais 1961: 54-55.

119 On his major contribution to South African jurisprudence, and case law in particular, see Zimmermann \& Sutherland 1999: passim.

120 On Ameshoff and Morice, see Roberts 1942: 347 and 372.

121 Mellet et al 1982: 98. On Wessels see Roberts 1942: 382-383 (he became Chief Justice in October 1932); on Curlewis see Roberts 1942: 354 (he became Chief Justice in October 1936); and on De Wet see Roberts 1942: 358 (he became Chief Justice in July 1939). 
A testimonial to the quality and reputation enjoyed by the Bench and Bar of the $Z A R$ in the 1890s is provided by James Bryce (later Viscount Bryce). This leading British lawyer, historian and politician visited the ZAR in 1895 . He wrote of the ZAR Bench and Bar in these years as follows: ${ }^{122}$

They [the advocates] and judges ... are the most cultivated and (except as regards political power) the leading section of society. It is a real pleasure to the European traveller to meet so many able and well-read men as the bench and bar of Pretoria contain.

\section{Judicial independence and integrity questioned}

John Kotzé, then, as the head of the judiciary and the leading jurisprudent in the country (and, for that matter, enjoying a deserved reputation in southern Africa) was a man of influence and stature in the ZAR. He and his fellow judges were not, however, immune from the (sometimes vitriolic) criticism levelled against the Boer state apparatus by the press on the Rand. It was known that John Kotzé himself not only held shares in the Rand Mines Company (controlled by the Corner House), but that he was also indebted to the Corner House. ${ }^{123} \mathrm{He}$ was not, though, the target of the uitlander press. Their targets were Judge Benedictus ("Benny") de Korte and Judge EJP Jorissen (father of SG Jorissen, who had died in 1889), both known to be indebted to Rand money lenders.

An article that appeared in the robustly anti-government newspaper, The Star, in February 1891, forcefully made the case that some judges, being underpaid by the state and having no security of tenure, were prone to running up debts. ${ }^{124}$ Their poor salaries and lack of tenure meant that they had to be executive-minded in their judgements in order not to incur the wrath of Paul Kruger and his executive. Their indebtedness meant that their neutrality and independence could not simply be assumed. In the language of modern political discourse, the judiciary was captured, neither independent from the executive nor, conceivably, from litigants that appeared before it.

The editor, Francis Dormer, former editor of the Cape Argus (controlled by Cecil John Rhodes), ${ }^{125}$ was charged with contempt of court. He was found guilty by a bench comprising Kotzé CJ, EJP Jorissen J and Morice $\mathrm{J}$ (the latter wrote a dissenting judgement) and fined heavily. ${ }^{126}$ In the course of a long and learned exposition of the Roman-Dutch law of contempt of court, Kotzé CJ posed the following rhetorical question in response to a defence claim that the court had no

122 See Bryce 1897: 387.

123 The shares were given to him as a so-called "friend" - and to State Secretary Leyds - at the launch of the company. See Cartwright 1965: 131; Wheatcroft 1986: 161; Meredith 2007: 303.

124 The article was published in full in In re Dormer (1891) 4 SAR 64 at 65-66.

125 On Dormer, see Meredith 2007: 115 and 197.

126 See In re Dormer (n 124) at 64-90. 
authority to exercise summary jurisdiction when contempt was allegedly committed beyond the courtroom: ${ }^{127}$

Shall the dignity and authority of this Supreme Court, so necessary for the proper discharge of its functions and duties - a portion, in fact, of the sovereignty entrusted to its keeping by the sovereign people [own emphasis added] - be left to the discretion of the AttorneyGeneral $[\mathrm{sic}]$ for that officer to decide whether there should be a prosecution ...?

This was a very different approach to the issue of sovereign power as adopted by him in his Austin-inspired judgement in McCorkindale (and confirmed by him in Doms). In the first place, he now recognised that the people (the volk) were sovereign, that the Boer political credo, de volk heeft de Koningstem (the people have the King's, that is, sovereign, voice) was not, as he had held in McCorkindale, merely "true in a moral, but certainly not in a legal, sense". ${ }^{28}$ Secondly, his view now was that the Volksraad was not the supreme or sovereign power in the state, to which all state power was subservient, but that the people had entrusted a "portion" of its sovereignty to the judicial authority.

\section{The presidential elections of 1893}

A presidential election was scheduled for early in 1893 and for the first time there was the real possibility that Kruger could lose the election. In the absence of a political party system, the progressives campaigned vigorously for Piet Joubert, the commandant-general and runner-up to Kruger (by some distance) in the previous election. Joubert's campaign chairman was Ewald Esselen, who was the moving spirit of the progressives. John Kotzé also made himself available as a candidate. His ticket was one of moderation. He wished to promote a true republicanism (not Kruger's republic of the volk), one that was governed in word and in deed by a constitution that functioned at a higher plain than ordinary laws, that provided sufficient guarantees for individual freedom and against the abuse of power. His campaign was therefore built around constitutional reform. ${ }^{129}$

Kotzé was never really in the race (which is probably why he did not resign his seat on the Bench). ${ }^{130}$ In the febrile political atmosphere of the 1893 election, one chose sides and vilified the opposition, one did not call for moderation and constitutional reform. He received all of eighty-one votes, Kruger and Joubert each receiving in excess of 7000 votes.

127 Idem 87.

128 See McCorkindale (n 12) at 211.

129 See Nathan 1941: 282; see, too, Kotzé 1894: 11.

130 He said he could not resign because there were important outstanding cases awaiting his decision: Nathan 1941: 282. 
Kruger and his so-called conservatives won the election, although by a mere 600 votes. Accusations of election-rigging prompted more than one recount, but the results stood. ${ }^{131}$ It was a bitter blow to the progressives (and to Kotzé) and defined political events for the next seven years.

In his inauguration address in May 1893, Kruger preached the virtues of unity and harmony among the volk (tweedracht - dissension - was anathema) and encouraged the uitlanders to serve one master only (the republican cause). ${ }^{132} \mathrm{He}$ told his audience that he stood before them, obedient to the call of the volk, in which he recognised the call of God. ${ }^{133}$ In effect, then, he was chosen by God and, because God revealed himself through the volkstem (the voice of the people), due deference had to be paid to the sovereign people. He would continue to insist on this article of political faith. In an address to the Volksraad in 1894, he stated the following (translated from the Dutch): ${ }^{134}$

A pure republican principle was, the people have the King's voice and a free voice is God's voice.

So, the freer the people were to express their views, undiluted by the interpretations of their representatives in the Volksraad, the closer one got to the real voice, which was God's voice. Kruger - the populist - was still in full voice in the mid-1890s and real political reform still a long way off.

\section{John Kotzé promotes constitution-driven democracy}

Despite Dormer having been found guilty of contempt of court for his attack on the judges in The Star, the press, in their unrelenting campaigns for political and economic reforms, continued to target the judiciary and to accuse its members of financial impropriety and bias, and the government of a failure to remunerate the judges properly. This created a feeling of disquiet even among the Boer population. ${ }^{135}$

A petition asking for a formal inquiry into the judiciary was discussed in the Volksraad in June 1893. When the judges were informed of this, they closed the doors of the Supreme Court. They discontinued their industrial action (on the same day) when they heard that the Volksraad would not launch an official investigation. It also prompted the judges, led by John Kotzé, to request the Volksraad to adopt legislation providing for a formal process to deal with allegations of judicial misconduct, in order to protect the dignity and independence of the judiciary. ${ }^{136}$

131 Idem 283-284.

132 See Meredith 2007: 292.

133 See Smit 1951: 14; Kleynhans 1966: 23-24.

134 Idem 18 and 23-24.

135 For what follows, see Van der Merwe 1979: 242-251. On judicial salaries, see Kahn 1958: 409 (including $\mathrm{n}$ 41).

136 See Anon 1894 CLJ: 179. 
In March and April 1894, Judge Benny de Korte became the prime target of a press onslaught. Henry Hess, editor of a Johannesburg weekly, the Critic, began a four-part series of articles exposing the financial affairs and extent of indebtedness of De Korte and the harm this did to the dignity and independence of the judiciary. Again, burghers petitioned the Volksraad to take action against De Korte and also against Jorissen, whom they accused of being rude, hostile and lacking in proper legal qualifications. ${ }^{137}$

The Kruger executive had decided in mid-June 1894 to raise a commando against a tribal chief in the Soutpansberg region, who resisted the tax yoke imposed on him by the government. A number of uitlanders were also commandeered for this purpose. Five British citizens refused to heed the call and sought a court order preventing them from being called up for commando duty. The matter was heard in June by Kotzé CJ, Jorissen J and Morice J. ${ }^{138}$ The court found that there was no blanket prohibition in international law against the $Z A R$ commandeering non-citizens to engage in military action and that the provisions of the Commando Law of 1882 were therefore valid. In the course of his judgement, Kotzé CJ made comments which confirmed the wholly different jurisprudential attitude he had begun to adopt since McCorkindale and Doms. In dismissing the objection by the state that the Supreme Court had no jurisdiction in what was essentially a military matter, he stated (in art 3 of the Grondwet), that the people (the volk) expressed the wish that it should be recognised by the civilised world as free and independent. He continued: ${ }^{139}$

This fundamental principle - bequeathed to us by the founders of the State - each of the three great departments of the State (the legislative, executive, and judicial) is bound to reverence and maintain. It is only by our strict observance of law and justice, as put in sect. 8 of our Grondwet, that we can retain our position among the free and civilised nations of the earth.

This, then, some ten years after McCorkindale, was the new jurisprudence espoused by John Kotzé: the judiciary in a civilised nation has the right and the solemn duty to uphold the Grondwet and the freedoms that the people in the Republic enjoy in accordance with the international law recognised by all civilised nations. Civilised values, individual freedoms, conceptions of law and justice - these, and not legislative whim, dominate, and they dominate because the volk expressly ordained it in the Grondwet to be so. Gone are the notions that "the Grondwet cannot be said to occupy a different or higher position than any ordinary law", that "this provision [art 12 of the Grondwet] is purely directory and in the nature of counsel or advice given by the legislature to its successors", and that the people are king "in a moral, but certainly not in a legal, sense". ${ }^{140}$

137 See Van der Merwe 1979: 243-245.

138 See Maynard v Field Cornet of Pretoria (1894) 1 OR 214.

139 Idem 221-222.

140 See McCorkindale (n 12) at 210, 211 and 212. 
By mid-June 1894, John Kotzé was becoming increasingly comfortable in his self-appointed role as defender of the constitution and as proponent of a constitutionbased republican democracy. Revisions to the Grondwet had been discussed since 1893 and judges (including Kotzé) had been asked for their input by a specially appointed Volksraad committee. The process was fraught, but represented democracy in action. ${ }^{141}$

In June he and all of the judges addressed a memorandum to the State President. ${ }^{142}$ In it they urged Kruger to see to it that urgent steps were taken to protect the dignity and independence of the judiciary. This would be achieved if revisions to the Grondwet then under discussion were to include a provision for the establishment of a special court to hear and dispose of allegations of judicial impropriety made by the press and public against individual judges; if judges were appointed for life; and if they were remunerated in terms of a special dispensation that was not subject to annual budgetary discussions. The memorandum stressed the vital importance to the stability and credibility of the state of preserving judicial independence from the head of state, who appointed the judges. Their duty, it was stated in the memorandum, should be discharged "in the name of the people [the volk] of the South African Republic":

The dignity of the Judge consists in his complete independence [within the province of his authority] of every power that can exert influence over his judgement, which should be regulated in accordance with what conscience dictates, and the law requires.

Kotzé's influence is clear: the memorandum called for fidelity to the sovereignty of the people, to conscience and to the requirements of the law (including the Grondwet), rather than to legislative and executive whim.

In July, the Bar adopted a resolution supportive of the measures proposed by the judges to protect judicial independence and integrity. ${ }^{143}$ The Volksraad heeded the calls from the influential Bench and Bar of the ZAR. It affirmed judicial independence as a cornerstone of republican democracy, approved a special procedure to investigate complaints made by the public against individual judges and appointed a committee to determine whether the complaints against Judges De Korte and Jorissen merited the invocation of the special procedure.

Confident in his role as the promoter of constitutional democracy and of judicial independence as an indispensable pillar of a constitutional state, Kotzé made two further extra-judicial forays into the cause of independence and constitutional probity before year end. In August 1894 the Second Volksraad sought to seize documents in possession of the registrar of the Supreme Court. Kotzé politely but firmly informed it that the documents could be perused at the registrar's office and, when he was

141 See Kotzé 1894: 12-13.

142 See, for an English translation of the memorandum, Anon 1894 CLJ 178-185.

143 Idem 176-178. 
summoned to appear before it, equally politely and firmly informed them that judges did not get "summoned" to appear before an arm of the legislature. Interestingly, Kruger supported Kotzé in the stance he took. ${ }^{144}$

In the same year he addressed a public gathering in Pretoria and presented to them his mature political views.

\section{Kotzé presents his political manifesto in 1894}

Kotzé's 1894 address was entitled "Het Stichting der Zuid Afrikaansche Republiek en Haare Grondwet" (the Foundation of the South African Republic and its Constitution). ${ }^{145}$ His purpose, in presenting an historical analysis of the establishment of the republic and the central role played by the Grondwet, was to inform his audience of the danger for the republic and its volk-door wiens stem alles behoort gereld [sic] te worden (through whose voice everything ought to be governed) - if there was a departure from the Grondwet on which it was founded. He presented to his audience a romanticised (and not entirely accurate) version of the events that led to the approval of the 1858 Grondwet, the "cornerstone of the Republic". ${ }^{146}$ The great republican principle to emerge from these events was that the voice of the people is the koningstem of the state, not the will of one or other leader with his personal entourage.${ }^{147}$ Kotzé's historical version was that the Grondwet represented a triumph of the "Volksraad party" (the Lydenburgers of Hendrik Bührmann and Cornelis Potgieter) against autocracy and was recognised as a super force representing the sacred will of the people, to serve as a bulwark against autocratic decision-making. ${ }^{148}$

In present times, he said, there was too much autocratic rule, and too much of the eenhoofdig bestier against which the volk wished to protect itself in the Grondwet. If the $Z A R$ wished to be taken seriously as a civilised nation, he said, then it needed to take its Grondwet seriously. The Grondwet recognised the separation of the three pillars of state, each exercising powers of state within the limits of their constitutionally delineated powers and obligations. The drafters were obviously influenced by the Constitution of the "Great Republic of North America". Respect for its constitution was what had made America a great country. In contrast, failure to recognise and implement these fundamental constitutional principles would imperil the independence of the state. Clearly, the ZAR was presently in danger of losing its independence. The best way to avert the crisis of governance in the country was to remain true to the provisions of the Grondwet. If the Volksraad were to cease from amending the Grondwet by mere resolution; to desist from passing hasty and "loose" (ie, imprecisely formulated) legislation without heeding the constitutional demand

144 See Van Oordt 1898: 599-600; Nathan 1941: 403.

145 See Kotzé 1894: passim.

146 Idem 10.

147 Idem 7.

148 Idem 8-10. On the real influence of Bührmann and Potgieter on constitution-drafting in the late 1850s, see Van der Merwe 2017a: 158-160. 
for proper consultation with the public; to respect the Grondwet and its volks-based sovereignty, all would be well. ${ }^{149}$

Too often the people themselves were at fault in allowing Kruger, his executive and the Volksraad to ride rough-shod over constitutional provisions, all in the name of avoiding dissension (tweedracht) among the burghers. The honest and robust expression of contrary views should never be confused with promoting disunity; instead, it is a sign of a healthy democracy for the (whole of the) volkstem to be heard. ${ }^{150}$

Influenced by his political views, John Kotzé's jurisprudence had now come full circle since McCorkindale: the volkstem had legal value, not merely moral value; the Grondwet was indeed foundational and "higher" than ordinary laws; the Constitution of the USA was of inestimable comparative value, not different and therefore inapplicable; the Volksraad might have the hoogste gezag (highest authority), but that authority could only be exercised within its constitutionally endowed sphere of competence.

By the second half of 1894, Kotzé had saddled his constitutional high-horse and was forging ahead. His was still a lone voice, however. Inspired by Kotzé and his fellow judges, the Volksraad committee tasked with revisions to the Grondwet had proposed that the Volksraad could only amend the Grondwet ("amend" also meant ignoring the Grondwet and, for example, passing laws by means of resolutions) if the amendment had been published in the Government Gazette for twelve months, in order for the volk to discuss and approve it. Under Kruger's influence the Volksraad vetoed this proposal. The Volksraad, not the Grondwet, was the highest authority in the land. ${ }^{151}$

The battle-lines between Paul Kruger and John Kotzé had been drawn.

\section{1895: Tensions between Kruger and Kotzé become palpable}

\section{Introduction}

The year 1895 would prove to be eventful for the political future of the $Z A R$ in so many respects. The much-awaited and long overdue railway line between Pretoria and Delagoa Bay was completed in 1894 and formally opened by State President Kruger in July 1895 amid much festivities. Its facilitation of direct access to the sea beyond British influence represented - symbolically if not in actual fact - a highwater mark of the ZAR's goal to be independent of Great Britain and its colonies. ${ }^{152}$

149 Kotzé 1894: 10-11 and 14.

150 Idem 12.

151 See Van Oordt 1898: 587-588.

152 Kotzé 1941: 218-223 provides an interesting personal recollection of the event. 
In September, Kruger and Leyds began to openly cultivate ties with Germany. They were well aware of how negatively Great Britain would react to such open invitations to Germany to involve itself in a part of the world in which Great Britain regarded itself as the paramount power. ${ }^{153}$ From mid-year, Cecil Rhodes and others secretly began to plot the overthrow of the Kruger government. They fed off the many economic and political grievances of the mining fraternity and of the uitlanders in general. It would eventually lead to the Jameson Raid in late December and early January 1896. The failure of the Jameson Raid and the imperial machinations that underpinned it would have major political consequences and would generate much bitterness and recrimination among both the Boers and the British. ${ }^{154}$

In judicial and legislative affairs, too, 1895 would prove ground-breaking and set in train a series of events that would have grave consequences three years later.

\section{John Kotzé signals his judicial conversion}

The Volksraad committee that was appointed in 1894 to consider whether the allegations of impropriety made against Judges De Korte and Jorissen were substantive enough to trigger a special court process, and to report by the end of the year, failed to fulfil its terms of reference. ${ }^{155}$ This was enough for Henry Hess to fire yet another salvo against De Korte in the January 1895 edition of the Critic. ${ }^{156}$ In it he openly accused Judge De Korte of bias towards a litigant to whom he was indebted in a case over which he presided.

This stung Benny de Korte into action. He laid a charge of criminal libel against Hess. Hess was charged with a contravention of the Press Law 11 of 1893. The case was heard in April 1895 by Kotzé CJ, Ameshoff J and Jorissen J and judgement was delivered in May. ${ }^{157}$ Although all three judges were of the view that Hess had not proved that De Korte was inappropriately biased towards the litigant in question, they found him not guilty: the section under which he was charged, namely section 3 of Law 11 of 1893, was poorly drafted and did not actually create an offence.

As one of his arguments, Hess had offered the defence that Law 11 of 1893 had no force of law, as it was passed in contravention of the procedural requirements for legislation prescribed in the Grondwet. ${ }^{158}$ Although the court found for Hess on a different ground, Kotzé CJ felt it necessary to add obiter comments on this defence. ${ }^{159}$

153 On Kruger's rapprochement with Germany see, inter alia, Kotzé 1941: 212-217; and Marais 1961: 46-49.

154 The most recent comprehensive history of the Jameson Raid is by Van Onselen 2017: chs 6-22 in particular.

155 They eventually met in July 1895 and found that no reasonable grounds existed to prefer formal charges against Judge De Korte (Judge Jorissen was not investigated). See Van der Merwe 1979: 249-250.

156 Idem 247-248.

157 See Hess $v$ The State (1895) 2 OR 112 at 112-129.

158 Idem 114-116.

159 Idem 115-116 
The trias politica, wrote Kotzé, was adopted in the Grondwet "and it is my duty as Judge, above all, to respect and maintain the Grondwet". The sovereign power of the people has been entrusted, through the Grondwet, "in various measures" to the legislature, the executive and the judiciary. The task of making laws was entrusted to the Volksraad, but "subject to certain limitations". This is not contrary to the notion of sovereignty, sovereign power or highest power. Huber ${ }^{160}$ stated that sovereign power may be limited by fundamental laws; and "even Austin ... does not deny the possibility that the exercise of this power may in some way or other be regulated by a constitution". ${ }^{161}$ This, Kotzé said, somewhat intriguingly, "seems to follow from the very nature of the case", by which he probably meant the nature of a constitution as a declaration of the people that served as the basis of government in a state. ${ }^{162}$

He then made a mental leap that did not follow from the nature of the case, nor was it logically preordained: "Each of the three powers," he wrote, "can consequently exercise its functions only in accordance with the Grondwet." It was therefore incumbent upon the judiciary, entrusted by the volk through the Grondwet with the sovereign power to interpret and apply the law, to test whether a law is valid in accordance with the Grondwet provisions. The testing right was "a tacit and necessary outcome of a popular Government under a constitution". ${ }^{163}$

Law 11 of 1893 was passed by means of a Volksraad resolution and there was no evidence that it was law that brooked no delay. It therefore did not comply with the requirements prescribed by the Grondwet for it to be valid law. The will of the legislature was not "duly expressed" in "due form" and "duly promulgated". ${ }^{164}$

He concluded his radical obiter pronouncement with the statement that "[f]urther consideration and study have induced me to alter my previous view on this point" ${ }^{165}$ The problem for Kotzé was that his altered view was not supported by the facts. The Grondwet, to be sure, was an expression of the King's voice of the people; it did serve as the basis of the government of the state; and it did grant to the legislature, the executive and the judiciary separate powers. But it did not have the foundational status that Kotzé, so recently enamoured of American constitutional doctrine, attributed to it. It was a malleable document that was amended time and again by the Volksraad, with the (overt and covert) acquiescence of the volk. The volk invested the highest authority in the Volksraad and it was up to the volk, not the judiciary, to determine whether the Volksraad exercised its highest authority appropriately or not. ${ }^{166}$ The Grondwet was not, and was never meant to be, the

160 In (1686) Heedendaegse Rechts-Geleertheyt, soo elders, als in Frieslandt Gebruikelijk 47.

161 Hess (n 157): 115. He referred to pp 241 and 242 of ch 6 of his edition (the 3rd) of Austin's Lectures on Jurisprudence, or the Philosophy of Positive Law.

162 Ibid.

163 Ibid.

164 Idem 116.

165 Ibid.

166 On the attitude towards the Grondwet adopted by the volk in the years immediately following the approval of the Grondwet in 1858, see Van der Merwe 2017b: 129-134. 
touchstone of a constitutional democracy as practised in the USA, however desirable Kotzé and many like-minded others wanted it to be. As long as the Grondwet was not revised to provide for its status as a super-norm, Kotzé's use of the Grondwet as his instrument for political reform, his campaign was misguided. Kotzé was committing the cardinal $\sin -\mathrm{a} \sin$ he himself had warned against in McCorkindale - of conflating what is with what ought to be.

\section{Robert E Brown provides the opportunity for Kotzé to confront Kruger head-on}

On 19 June 1895 two farms (Witfontein and Luipaardsvlei) on the western edge of the Witwatersrand (near the modern town of Randfontein) were proclaimed as public goldfields in the Government Gazette, to be opened to the public for the pegging off of gold claims on 19 July. ${ }^{167}$ Since there was a widely held belief that a portion of the main reef ran through these farms, interest in these goldfields were at fever pitch.

Robert E Brown was one of those who believed in the potential wealth to be generated from these public diggings. He was a thirty-year old mining engineer from Philadelphia in the USA, who had come to the Rand in 1894 and was then working as a consulting engineer for one of the mining companies. ${ }^{168} \mathrm{He}$ planned meticulously in order to buy as many licences for the pegging off of the claims on the day as he could.

On the morning of 19 July, when Brown and others arrived early to buy their licences from the responsible clerk, it was clear that the officials were unprepared for the hundreds of aggressive prospectors who had descended on the public diggings. The mining commissioner telegraphed to the Executive Council in Pretoria, who took a resolution that same day to provisionally suspend the opening of the goldfields to the public until better arrangements could be made. Brown was not satisfied with this decision. He tendered his money to the official (as did others), who did not accept the money, but nevertheless acknowledged in writing that Brown had tendered the money to buy 1200 claims. Brown and his team then proceeded to peg off the claims. Three days later he did the same at the second public digging, pegging off 800 claims despite the provisional suspension of the proclamation.

On the following day, 20 July, a proclamation dated 18 July and signed by the state president on that date, was published in an extraordinary Gazette, confirming the resolution of the Executive Council to suspend the opening of the goldfields. Two days later Brown instituted an action in the Supreme Court against State Secretary Leyds and the responsible clerk at the public digging. He sought an order declaring

167 For what follows see, in particular, Brown v Leyds NO (1897) 4 OR 17 at 17-18 and 19-22.

168 On Brown's background see, in particular, Van Onselen 2017: 80, 114-115 and 180. He immersed himself in the politics surrounding the Jameson Raid and the uitlander discontent, reputedly as an agent for the Boers (at least initially). 
his pegging off of his claims to be lawful and that he was therefore entitled to mine them. On 26 July Kruger and his executive, having become aware of Brown's action, asked the Second Volksraad (it was responsible for mining affairs) to endorse the action taken by the Executive Council in issuing the 20 July proclamation. This it duly did, on the same day, and on 31 July authorised the executive to postpone the proclamation of the two public diggings for at least another three weeks in order to make proper arrangements. The First Volksraad confirmed these resolutions by resolution - on 1 August 1895, which resolutions were duly published in the Gazette on the same day. The Witfontein farm was eventually reproclaimed a public goldfield on 30 August, at which date claims were issued on the basis of a lottery system. Brown did not participate.

To John Kotzé these circumstances must have been as manna sent from heaven. They provided a perfect opportunity for him to adjudicate on the constitutionality, and therefore validity, of resolutions passed by the Volksraad, and on the place and role of the Grondwet as a mechanism for the exercise of testing rights by the judiciary - in short, to assert the virtues of constitutional democracy in the ZAR of the 1890s.

Brown's application was heard in the Supreme Court in Pretoria from 15 to 19 November. The matter was argued before Kotzé CJ, Ameshoff J and Morice J. For Brown appeared Wessels and Curlewis, both later chief justices of the Union of South Africa. For the state appeared State Attorney Esselen (who was also the leader of the Bar at the time) and two juniors. It was to be a battle between the best legal minds in the $Z A R$ at the time, presided over by another first-rate legal mind.

\section{Kruger and Kotzé meet to discuss their differences}

Kruger was astute enough to recognise the potential for real conflict between him and Kotzé posed by Brown's action, especially after Kotzé's obiter judgement in Hess in May. He invited Kotzé to meet with him on 7 September 1895. ${ }^{169}$

He had been made aware, he told Kotzé, that in his Hess judgement Kotzé had stated that his decisions in McCorkindale and Hess were wrong. He failed to understand how Kotzé could think that a court need not be bound by a resolution of the Volksraad. The law was clear: once a law or resolution had been signed by the state president and published in the Government Gazette, it had full force and effect. Only the volk, through petitions to the Volksraad, can force the Volksraad to reconsider. The brotherhood that existed between him and Kotzé must not suffer, but it would most certainly suffer if Kotzé persisted in the belief that a court can declare a resolution invalid. Then the volk and the Volksraad will rise against the court and that would place him (Kruger) in the invidious position of having to suspend him. ${ }^{170}$

169 Kotzé's notes of this meeting were published in 1898 CLJ 90-93.

170 To his credit, Kruger had always maintained in the Volksraad that the Grondwet was not a law to be trifled with and that it should be amended only if the Volksraad, as the highest authority, deemed it clearly appropriate to do so: see Smit 1951: 177-178. 
Kotzé's reply did not placate Kruger: he would not promise, he said to Kruger, to always enforce Volksraad resolutions. He can only promise to do his duty in accordance with the dictates of the law and his conscience. The volk, he told Kruger, is too sensible to generate conflict between the judiciary and the legislature. There would be no problem if the court maintains the Grondwet and other laws.

The die was therefore clearly cast for the battle of wills that was to play itself out some eighteen months later between them against the background of the Brown $v$ Leyds judgement.

After hearing argument in Brown v Leyds, Kotzé had occasion, in early December, to express himself judicially on the foundational importance he attached to the Grondwet. Johannes Esser had been sworn in by State Secretary Leyds as a judge to preside over the circuit court in the eastern part of the country. ${ }^{171}$ Leyds had done so without consulting any of the judges. The validity of Esser's appointment, and therefore of his discharge of his judicial duties as circuit-court judge, was argued before a full bench in early December. ${ }^{172}$ The court found that Esser had not been sworn in in accordance with the provisions of the Grondwet, that his appointment was therefore irregular, and that the conviction and imposition of the death penalty on one Snuif while on circuit had to be set aside. In the course of his brief judgement, Kotzé CJ commented that "[t]he only safeguard which the people have is the faithful observance of the Grondwet and of the pure principles of the Constitution". ${ }^{173}$ Even after his interview with the state president in September, he was clearly not going to budge on what he believed to be his principled stance.

\section{Concluding remarks}

By the end of 1895 John Kotzé had done an about-turn on his views on state sovereignty as expressed in 1884 in McCorkindale and confirmed in 1887 in Doms. He had recognised that any case he wished to build for the supremacy of the constitution in the South African Republic needed to take seriously the insistence by the burghers of the ZAR that de volk heeft de Koningstem (the people have the King's voice) as a legal principle and not to attach mere moral value to it as he had done in McCorkindale. He believed their sovereignty to be captured in the 1858 Grondwet and proceeded to attach to the Grondwet overriding importance as a conduit of the sovereignty of the people in a republican democracy. In doing so he found himself able to build a case, carefully but inexorably, for a republican government of the people that had all the hallmarks of the well-established constitutional democracy of the United States of America. It allowed him to argue that the highest authority in the state, that of the Volksraad, could be limited. More particularly, it could be

171 He became a permanently-appointed judge soon after. On Esser, see Roberts 1942: 359.

172 See Snuifv The State (1895) 2 OR 294.

173 Idem at 297. 
limited in a way that promoted law and justice and that acted as a counterfoil to the autocratic tendencies Paul Kruger and his executive were beginning to exhibit all too frequently by manipulating sentiment in the Volksraad and by passing legislation in any manner it deemed appropriate and in respect of any matter it deemed a threat to Boer independence.

Paul Kruger, long an adherent of the notion that de volk heeft de Koningstem, continued in these years to promote the supreme authority of the volk in all matters. His approach, however, differed crucially from that of Kotzé. To him, the volkstem (voice of the people) was a manifestation of the voice of God and he, as their duly elected leader, was the conduit through which the hopes and aspirations and, importantly, their independence as a God-fearing nation, was to be borne. He and the Volksraad were the servants of the people, ready to do their bidding. The Grondwet was an important expression of the voice of the people, but it had not the immutability Kotzé attached to it and, in any event, the Volksraad had explicitly been granted the highest authority in the state by the people.

By 1895 the fault-line between Kotzé's and Kruger's conceptions of the sovereignty of the people had become clearly delineated. When Robert Brown disputed the authority of the Volksraad to deny him his right to peg off claims on a proclaimed goldfield, by means of hastily drafted and implemented resolutions, the die was cast.

The strained atmosphere of conflict and grievance between Boer and uitlander and the spectre of imperial Britain seeking an opportunity for intervention in republican affairs all contributed significantly to the clash of wills between state president and chief justice that erupted after John Kotzé handed down his judgement in Brown v Leyds in 1897. These events will form the subject-matter of the next and final article in this series.

\section{BIBLIOGRAPHY}

\section{Books and articles}

Anonymous (1894) "What the position of the judges of the High Court of the South African Republic should be" Cape Law Journal 11: 176-185

Anonymous (1898) "Raad and Bench" Cape Law Journal 15: 94-108

Austin, J (1885) Lectures on Jurisprudence, or the Philosophy of Positive Law (London)

Bossenbroek, M (2014) Die Boereoorlog (Pretoria) (trl into Afrikaans by A-M Mischke)

Botha, PR (1926) Die Staatkundige Ontwikkeling van die Suid-Afrikaanse Republiek onder Krüger en Leyds (Amsterdam)

Breytenbach, JH (ed) (1950) Notule van die Volksraad van die Suid-Afrikaanse Republiek II (Cape Town) (cited as Volksraadsnotule II)

Bryce, J (1897) Impressions of South Africa (London) 


\section{DEREK VAN DER MERWE}

Cohen, L (1976, reprint of 1924 ed) Reminiscences of Johannesburg and London (Johannesburg) Cartwright, AP (1965) The Corner House: The Early History of Johannesburg (Johannesburg)

Davenport, J (2013) Digging Deep. A History of Mining in South Africa 1852-2002 (Johannesburg) De Groot, H (1625) De Iure Belli ac Pacis (Paris)

Huber, U (1686) Heedendaegse Rechts-Geleertheyt, soo elders, als in Frieslandt Gebruikelijk (Leeuwaarden)

Jeppe, F \& Kotzé, JG (1887) De Locale Wetten der Zuid Afrikaansche Republiek 1849-1885 (Pretoria)

Kahn, E (1958) "The history of the administration of justice in the South African Republic" SALJ 75: $397-417$

Kahn, E (1991) Law, Life and Laughter (Cape Town)

Kaye, H (1978) The Tycoon and the President (Johannesburg)

Kleynhans, WA (1966) Volksregering in die Zuid-Afrikaansche Republiek: Die Rol van Memories (Pretoria)

Kotzé, JG (1894) Het Stichting der Zuid Afrikaansche Republiek en haare Grondwet (Pretoria)

Kotzé, JG (1934) Biographical Memoirs and Reminiscences vol 1 (Cape Town)

Kotzé, JG (1941) Memoirs and Reminiscences vol 2, ed by BA Tindall (Cape Town)

Marais, JS (1961) The Fall of Kruger's Republic (Oxford)

Mellet, HF, Scott S \& Van Warmelo P (eds) (1982) Our Legal Heritage (Pretoria)

Meredith, M (2007) Diamonds, Gold and War (New York)

Nathan, M (1932) “The South African Bench and Bar” South African Law Times 1: 13-14

Nathan, M (1941) Paul Kruger. His Life and Times (Durban)

Pelzer, AN (1970) "Die Suid-Afrikaanse Republiek se ywer vir 'n eie hawe en A McCorkindale se rol in verband daarmee" Historia 15(3): 146-163

Roberts, AA (1942) A South African Legal Bibliography (Pretoria)

Smit, FP (1951) Die Staatsopvattinge van Paul Kruger (Pretoria)

Van der Merwe, C (2015) Donker Stroom Eugène Marais en die Anglo-Boereoorlog (Cape Town)

Van der Merwe, D (1979) "Skuld en skandaal in die Hooggeregshof van die ZAR" De Jure 12: 242-251

Van der Merwe, D (1984) "Enigmatic Ewald Esselen” Codicillus 23(2): 15-23

Van der Merwe, D (2017a) “Brown v Leyds NO (1897) 4 OR 17: A constitutional drama in four acts. Act one: The 1858 Constitution of the Zuid-Afrikaansche Republiek" Fundamina 23(1): 111-165

Van der Merwe, D (2017b) “Brown v Leyds NO (1897) 4 OR 17: A constitutional drama in four acts. Act two: The 1858 ZAR constitution, malleable instrument of Transvaal Realpolitik (1859-1881)" Fundamina 23(2): 118-175

Van Leeuwen, S (1664) Het Rooms-Hollands Regt (Amsterdam)

Van Niekerk, LE (1985) Kruger se Regterhand (Pretoria)

Van Onselen, C (2017) The Cowboy Capitalist John Hays Hammond, the American West and the Jameson Raid (Johannesburg) 
Van Oordt, JF (1898) Paul Kruger en de Opkomst der Zuid-Afrikaansche Republiek (Cape Town) Wheatcroft, G (1986) The Randlords: The Men who Made South Africa (Johannesburg)

Zimmermann, R \& Sutherland, P (1999) ““... a true science and not a feigned one’: JG Kotzé (1849-1940), Chief Justice der Südafrikanischen Republik (Transvaal)” Zeitschrift der Savigny-Stiftung für Rechtsgeschichte 116: 147-194

\section{Cases}

Brown v Leyds NO (1897) 4 OR 17

Dean and Johnson v Field (1885) 1 Roscoe Reports 165

Executors of McCorkindale v Bok NO (1884) 1 SAR 202

Hess $v$ The State (1895) 2 OR 112

In re Dormer (1891) 4 SAR 64

Maynard v Field Cornet of Pretoria (1894) 1 OR 214

Nabal v Bok (1883) 1 SAR 60

Snuif v The State (1895) 2 OR 294

State $v$ Nellmapius (1886) 2 SAR 121

Trustees in the Insolvent Estate of Theodore Doms v Bok NO (1887) 2 SAR 189

\section{Archival sources}

National Archives Repository (Public Records of Former Transvaal Province and Its Predecessors as well as of Magistrates and Local Authorities) (TAB)

Staatsprokureurstukke 25/1877

ZAR Staatskoerant (Government Gazette) ns 52, 57 and 61 